In Cooperation with the American Water Works Association Research Foundation

\title{
Augmenting Two-Dimensional Hydrodynamic Simulations with Measured Velocity Data to Identify Flow Paths as a Function of Depth on Upper St. Clair River in the Great Lakes Basin
}

Scientific Investigations Report 2005-5081 


\section{Augmenting Two-Dimensional Hydrodynamic Simulations with Measured Velocity Data to Identify Flow Paths as a Function of Depth on Upper St. Clair River in the Great Lakes Basin}

By David J. Holtschlag and John A. Koschik

Prepared in cooperation with the

American Water Works Association Research Foundation

Scientific Investigations Report 2005-5081 


\section{U.S. Department of the Interior \\ Gale A. Norton, Secretary}

\section{U.S. Geological Survey Charles G. Groat, Director}

\section{U.S. Geological Survey, Reston, Virginia 2005}

For sale by U.S. Geological Survey, Information Services

Box 25286, Denver Federal Center

Denver, CO 80225

For more information about the USGS and its products:

Telephone: 1-888-ASK-USGS

World Wide Web: http://www.usgs.gov

Any use of trade, firm, or product names is for descriptive purposes only and does not imply endorsement by the U.S. Government

Although this report is in the public domain, permission must be secured from the individual copyright owners to reproduce any copyrighted material contained within this report.

Suggested citation:

Holtschlag, D.J., and Koschik, J.A., 2005, Augmenting two-dimensional hydrodynamic simulations with measured velocity data to identify flow paths as a function of depth on Upper St. Clair River in the Great Lakes Basin: U.S. Geological Survey, Scientific-Investigations Report 2005-5081, 42 p. 


\section{Contents}

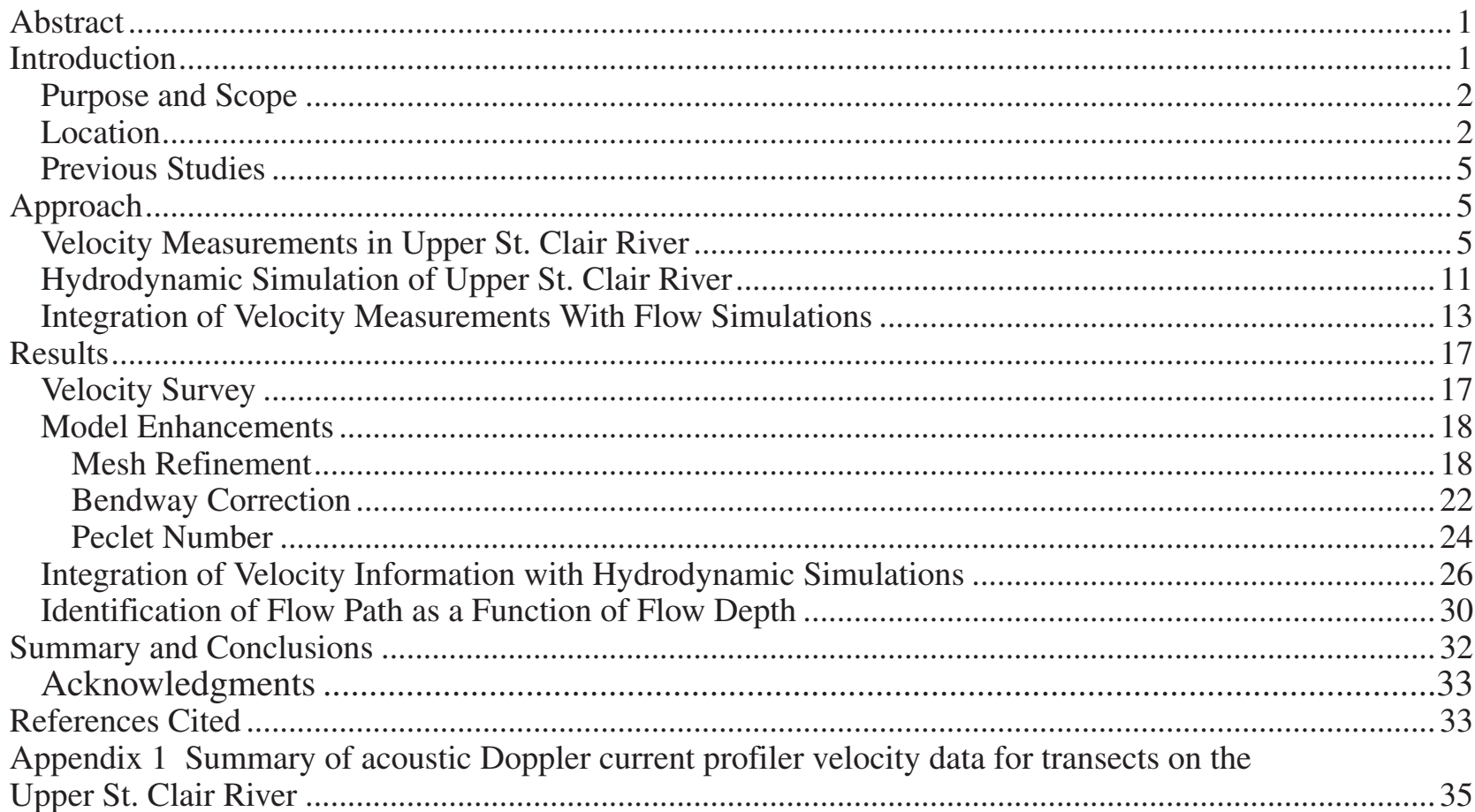

\section{Figures}

1-6. Maps showing--

1. Upper St. Clair River study area in the Great Lakes Basin ................................................................

2. Water depths in the northern part of Upper St. Clair River .........................................................

3. Acoustic Doppler current profiler (ADCP) transects in Upper St. Clair River (panel 1)...................6

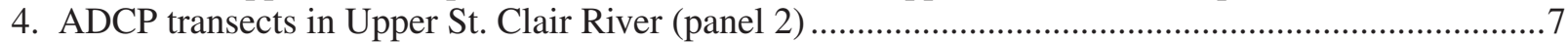

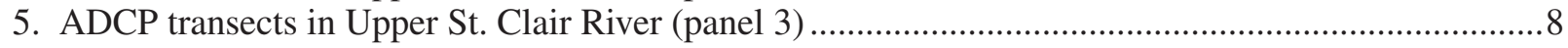

6. ADCP transects in Upper St. Clair River (panel 4) ......................................................................

7. Histogram of velocity measurement distribution by layer during the July 2003 ADCP survey

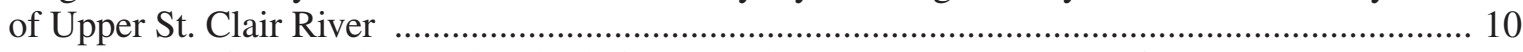

8. Graph showing flows and water levels during the July 2003 ADCP survey of Upper St. Clair River ......................................................................................................................... 11

9. Map showing the finite-element mesh for the public water intake version and the refined version of the Upper St. Clair River model .................................................................................12

10. Variogram showing spatial structure of horizontal velocity innovations in layer 1 .........................15

11. Graph showing the cumulative distribution function of flow velocities measured during the July 2003 ADCP survey of Upper St. Clair River........................................................................... 18

12-14. Graphs showing--

12. Relation between easting velocity components simulated by the public water intake version and the refined version of the Upper St. Clair River hydrodynamic model .....

13. Relation between northing velocity components simulated by the public water intake version and the refined versions of the Upper St. Clair River hydrodynamic model.

14. Relation between water levels simulated by the public water intake version and the refined 
version of the Upper St. Clair River hydrodynamic model.........................................................20

15-17. Maps showing--

15. Simulated velocities downstream from the Blue Water Bridge on Upper St. Clair River using the refined mesh without the bendway correction and with a Peclet number of 21.9...........21

16. Simulated vorticity in the northern part of Upper St. Clair River

17. Change in velocities simulated by use of the refined mesh with implementation of the Bendway Correction and a Peclet number of 21.9

18. Graph showing relation between simulated and measured velocities averaged within elements for the initial Peclet number of 21.9 and the revised Peclet number of 200.

19. Map showing simulated velocity field downstream from the Blue Water Bridge on Upper St. Clair River on refined mesh with Bendway Correction and Peclet number of 200...................25

20. Graph showing the relation between average measured and integrated velocities in layer 1 of Upper St. Clair River

21-22. Maps showing--

21. Integrated near-surface velocities in layer 1 of Upper St. Clair River downstream from the Blue Water Bridge

22. Flow paths as a function of depth (layer) in Upper St. Clair River from reverse particletracking for average flow conditions during July 1-3, 2003.

\section{Tables}

1. Distribution of acoustic Doppler current profiler velocity innovations among layers. .......................14

2. Parameters used in model variograms of velocity innovations............................................................ 17

3. Summary of relations between element-averaged measured and integrated velocities........................28 


\section{Conversion Factors and Datums}

\begin{tabular}{|c|c|c|}
\hline Multiply & By & To obtain \\
\hline \multicolumn{3}{|c|}{ Length } \\
\hline International foot (Int. ft) & 0.3048 (exactly) & meter $(\mathrm{m})$ \\
\hline U.S. Survey foot $(\mathrm{ft})$ & 0.3048006 (approximately) & meter $(\mathrm{m})$ \\
\hline mile (mi) & 1.609 & kilometer (km) \\
\hline meter (m) & 3.2808 & foot $(\mathrm{ft})$ \\
\hline centimeter $(\mathrm{cm})$ & 0.3937 & inch (in.) \\
\hline \multicolumn{3}{|c|}{ Area } \\
\hline square foot $\left(\mathrm{ft}^{2}\right)$ & 0.09290 & square meter $\left(\mathrm{m}^{2}\right)$ \\
\hline square mile $\left(\mathrm{mi}^{2}\right)$ & 259.0 & hectare (ha) \\
\hline square mile $\left(\mathrm{mi}^{2}\right)$ & 2.590 & $\begin{array}{l}\text { square kilometer } \\
\left(\mathrm{km}^{2}\right)\end{array}$ \\
\hline \multicolumn{3}{|c|}{ Flow rate } \\
\hline foot per second $(\mathrm{ft} / \mathrm{s})$ & 0.3048 & $\begin{array}{l}\text { meter per second } \\
\quad(\mathrm{m} / \mathrm{s})\end{array}$ \\
\hline cubic foot per second $\left(\mathrm{ft}^{3} / \mathrm{s}\right)$ & 0.02832 & $\begin{array}{r}\text { cubic meter per } \\
\text { second }\left(\mathrm{m}^{3} / \mathrm{s}\right)\end{array}$ \\
\hline
\end{tabular}

Temperature in degrees Celsius $\left({ }^{\circ} \mathrm{C}\right)$ may be converted to degrees Fahrenheit $\left({ }^{\circ} \mathrm{F}\right)$ as follows:

${ }^{\circ} \mathrm{F}=\left(1.8 x^{\circ} \mathrm{C}\right)+32$

Temperature in degrees Fahrenheit $\left({ }^{\circ} \mathrm{F}\right)$ may be converted to degrees Celsius $\left({ }^{\circ} \mathrm{C}\right)$ as follows:

${ }^{\circ} \mathrm{C}=\left({ }^{\circ} \mathrm{F}-32\right) / 1.8$

Vertical coordinate information is referenced to the International Great Lakes Datum of 1985 (IGLD 85).

Horizontal coordinate information is referenced to the Michigan State Plane Coordinate System (MSPCS), Southern Zone (2113), based on the North American Datum of 1983 (NAD 83). MSPCS units are in International feet.

Altitude, as used in this report, refers to distance above the vertical datum.

Sampling and signal frequencies of acoustic Doppler current profilers are given in hertz $(\mathrm{Hz})$ and kilohertz $(\mathrm{kHz})$. 


\title{
Augmenting Two-Dimensional Hydrodynamic Simulations with Measured Velocity Data to Identify Flow Paths as a Function of Depth on Upper St. Clair River in the Great Lakes Basin
}

\author{
By David J. Holtschlag' and John A. Koschik ${ }^{2}$
}

\begin{abstract}
Upper St. Clair River, which receives outflow from Lake Huron, is characterized by flow velocities that exceed 7 feet per second and significant channel curvature that creates complex flow patterns downstream from the Blue Water Bridge in the Port Huron, Michigan, and Sarnia, Ontario, area. Discrepancies were detected between depth-averaged velocities previously simulated by a two-dimensional (2D) hydrodynamic model and surface velocities determined from drifting buoy deployments. A detailed ADCP (acoustic Doppler current profiler) survey was done on Upper St. Clair River during July 1-3, 2003, to help resolve these discrepancies.

As part of this study, a refined finite-element mesh of the hydrodynamic model used to identify source areas to public water intakes was developed for Upper St. Clair River. In addition, a numerical procedure was used to account for radial accelerations, which cause secondary flow patterns near channel bends. The refined model was recalibrated to better reproduce local velocities measured in the ADCP survey. ADCP data also were used to help resolve the remaining discrepancies between simulated and measured velocities and to describe variations in velocity with depth.

Velocity data from ADCP surveys have significant local variability, and statistical processing is needed to compute reliable point estimates. In this study, velocity innovations were computed for seven depth layers posited within the river as the differences between measured and simulated velocities. For each layer, the spatial correlation of velocity innovations was characterized by use of variogram analysis. Results were used with kriging to compute expected innovations within each layer at applicable model nodes. Expected innovations were added to simulated velocities to form integrated velocities, which were used with reverse particle tracking to identify the expected flow path near a sewage outfall as a function of flow depth.

Expected particle paths generated by use of the integrated velocities showed that surface velocities in the upper layers tended to originate nearer the Canadian shoreline than velocities near the channel bottom in the lower layers. Therefore, flow paths to U.S. public water intakes located on the river bottom are more likely to be in the United States than withdrawals near the water surface. Integrated velocities in the upper layers are generally consistent with the surface velocities indicated by drifting-buoy deployments. Information in the 2D hydrodynamic model and the ADCP measurements was insufficient to describe the vertical flow component. This limitation resulted in the inability to account for vertical movements on expected flow paths through Upper St. Clair River. A three dimensional hydrodynamic model would be needed to account for these effects.
\end{abstract}

\section{Introduction}

Simulated velocities from a two-dimensional (2D) hydrodynamic model were used to describe the advective movement of water through the St. Clair-Detroit River Waterway (Holtschlag and Koschik, 2004). This advective component was used with particle tracking to identify source areas to U.S. public water intakes. Depth-integrated velocities simulated by the model generally paralleled the shoreline in Upper St. Clair River. Source areas for the city of Port Huron's public water intakes were consequently mapped to the U.S. side of the waterway upstream from the intakes. Simulated depth-integrated velocities, however, were inconsistent with surface velocities indicated by drifting-buoy deployments, which showed that near-surface water flowed from the Canadian to the U.S. side of the waterway within Upper St. Clair River (Holtschlag and Aichele, 2001). Therefore, the

\footnotetext{
${ }^{1}$ By David J. Holtschlag

${ }^{2}$ John A. Koschik
} 


\section{Augementing Two-Dimensional Hydrodynamic Simulations with Measured Velocity Data to Identify Flow Paths as a Function of Depth on Upper St. Clair River in the Great Lakes Basin}

simulated velocities may not be sufficient to describe the complex flow pattern in Upper St. Clair River, and source areas to the city of Port Huron's public water intakes may be inadequately identified.

In response to the discrepancies between near-surface flow velocities indicated by drifting-buoy deployments and depthaveraged velocities indicated by model simulations in Upper St. Clair River, the U.S. Geological Survey (USGS) in cooperation with the American Water Works Association Research Foundation (AwwaRF), began a study to resolve these discrepancies.

\section{Purpose and Scope}

The purpose of this report is to refine the identification of flow paths to the city of Port Huron's public water intake. Improvements are based on enhancing the calibration and resolution of depth-integrated velocities simulated by an existing 2D hydrodynamic model and on adjusting depth-integrated velocities to reflect systematic variations in flow velocities with depth, as measured by means of detailed ADCP (acoustic Doppler current profiler) surveys of flow velocity in Upper St. Clair River. Only that part of the existing hydrodynamic model from the head of St. Clair River to the mouth of Black River, a distance of about $2.5 \mathrm{mi}$, was recalibrated and refined.

\section{Location}

Upper St. Clair River is part of the international boundary between the United States and Canada (XFigure 1X). The river, which connects Lake Huron with Lake St. Clair, is a major navigational and recreational resource of the Great Lakes Basin. St. Clair River extends about $39 \mathrm{mi}$ from its head at the outlet of Lake Huron near Port Huron, Mich., to an extensive delta area that discharges into Lake St. Clair. Throughout the river's length, water levels (water-surface elevations) decrease about $5 \mathrm{ft}$ as an average of $182,000 \mathrm{ft}^{3} / \mathrm{s}$ is discharged from a drainage area of about 222,400 $\mathrm{mi}^{2}$. Local tributaries to Upper St. Clair River include Black River, which has a drainage area of about $746 \mathrm{mi}^{2}$ and an average flow of about $489 \mathrm{ft}^{3} / \mathrm{s}$.

In this report, Upper St. Clair River refers to the reach of St. Clair River from the National Oceanic and Atmospheric Administration (NOAA) water-level gaging station Fort Gratiot, Mich., (station 9014098), which is near the head of St. Clair River, to the NOAA station Mouth of the Black River, Mich. (station 9014090), a distance of about 2.5 mi. Within this reach, water levels commonly fall about $0.6 \mathrm{ft}$. Depths of flow can be as great as $78 \mathrm{ft}$, with maximum depths in the northern half of the river (fig. 2). Upper St. Clair River bends toward the left (east) as water flows generally towards the south. In some areas,

flow velocities exceed $7 \mathrm{ft} / \mathrm{s}$. Complex secondary flow circulation patterns, which are associated with high flow velocities and channel curvature, have been measured downstream from the Blue Water Bridge. 


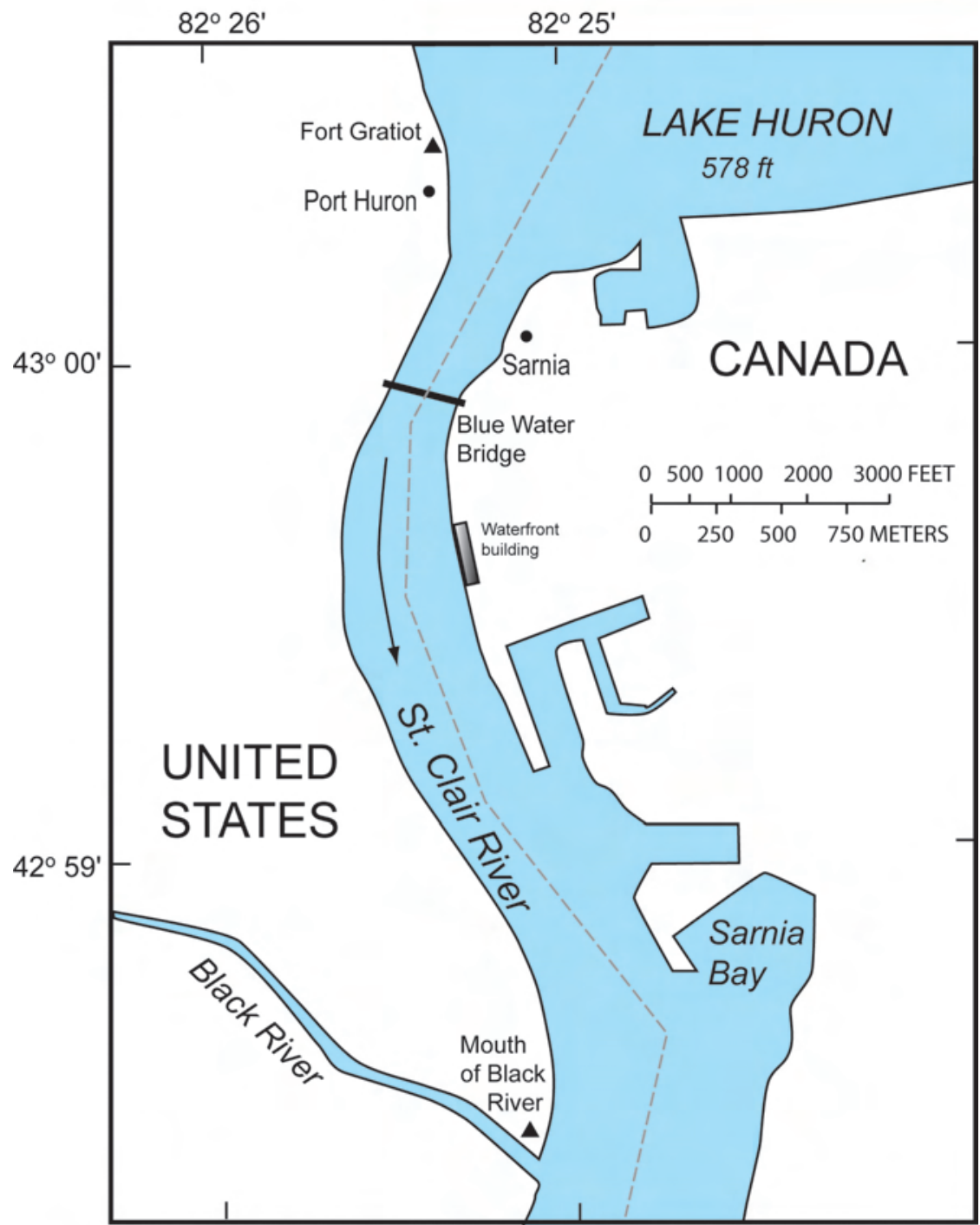

Base from National Oceanic and Atmospheric Administration 1:15,000

EXPLANATION

$\Delta$ Water-level gaging station

-- International boundary

- City

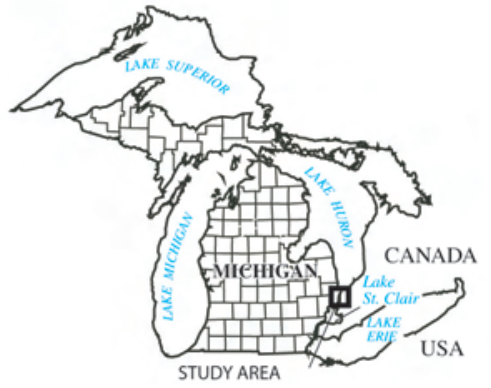

Figure 1. Upper St. Clair River study area in the Great Lakes Basin. 

Function of Depth on Upper St. Clair River in the Great Lakes Basin

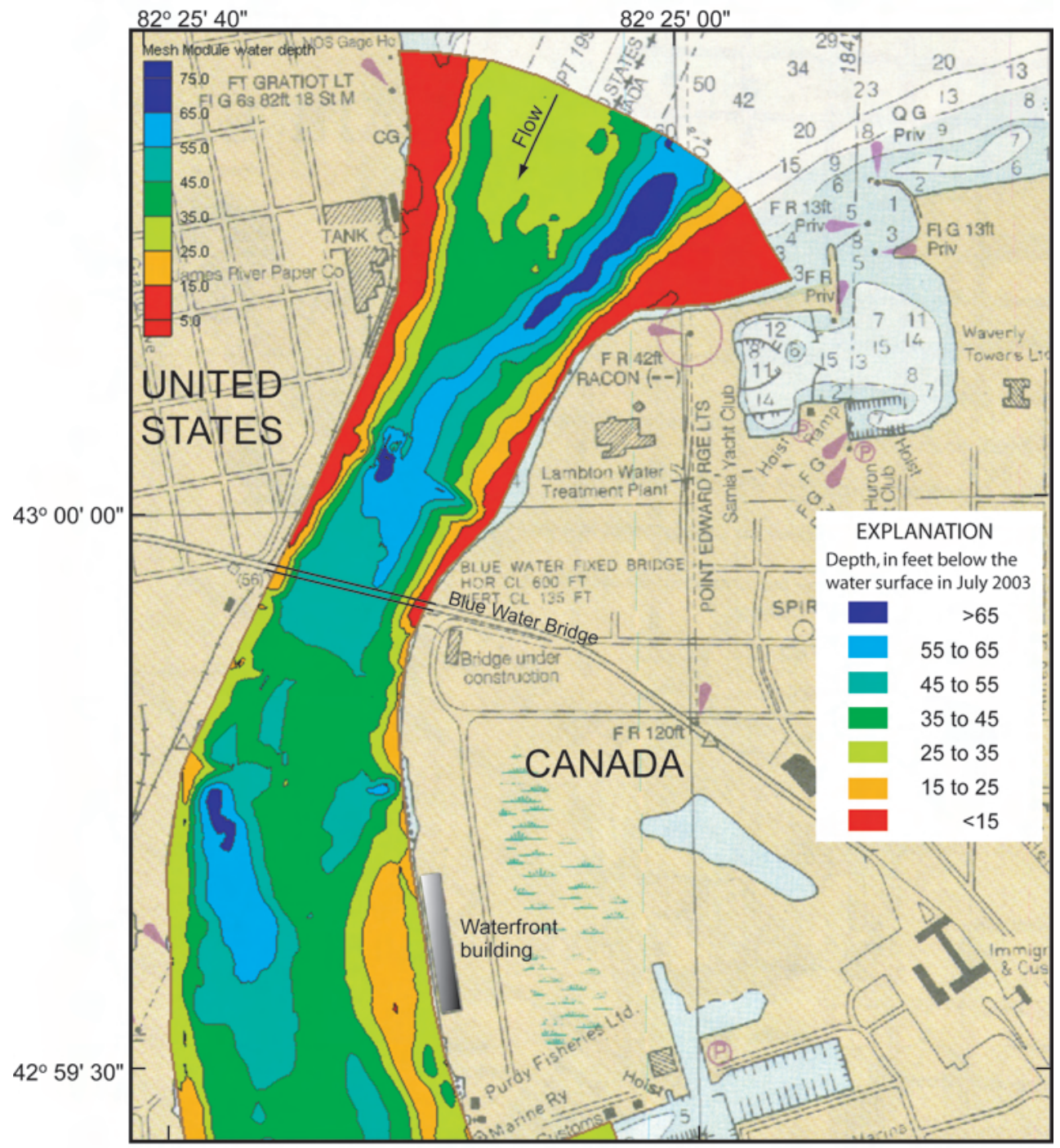

Base from National Oceanic and Atmospheric Administration 1:15,000 chart, 1999.

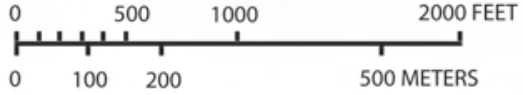

Figure 2. Water depths in the northern part of Upper St. Clair River. 


\section{Previous Studies}

Numerous investigators have contributed to the understanding of flow on the St. Clair-Detroit River Waterway. Schwab and others (1989) compared currents measured on Lake St. Clair with particle-tracking results based on 2D hydrodynamic simulations. Tsanis and others (1996) implemented the RMA2 hydrodynamic model on St. Clair and Detroit Rivers; results indicated that simulated currents closely matched field measurements of drifting buoys. Williamson and others (1997) developed a 2D finite-element model of the St. Clair-Detroit River system for the Canadian Coast Guard for water-level prediction and assessment of structures in the river systems. The U.S. Army Corps of Engineers (USACE) Waterway Experiment Station (WES) in Vicksburg, Miss., developed a prototype 2D model of the St. Clair-Detroit River Waterway for the Detroit District USACE (Ron Heath, USACE-WES, written commun., 1999). The resulting model was modified and adapted for use in a joint study by Environment Canada and the Detroit District USACE, to assess the effects of encroachments on water levels in St. Clair and Detroit Rivers (Aaron Thompson, Environment Canada, written commun., July 2000). An RMA2 hydrodynamic model was initially applied to the St. Clair-Detroit River Waterway by matching water-surface elevations and flows in numerous branches to measured values (Holtschlag and Koschik, 2002). Subsequently, this model was refined by including depth-averaged velocities from ADCP surveys in the calibration criteria. Techniques used to map source areas to public water intakes are documented by Holtschlag and Koschik (2004).

\section{Approach}

The study described in this report integrates velocity measurements and hydrodynamic model simulations in Upper St. Clair River to identify flow paths near sewage outfalls used by the city of Port Huron, Mich. The velocity data were a basis for evaluating and enhancing part of an existing hydrodynamic model of the St. Clair-Detroit River Waterway that was developed for the Michigan Source Water Assessment Program (Holtschlag and Koschik, 2004). Finally, the velocity data were integrated with model simulations to describe the variation of horizontal flow velocities with depth.

\section{Velocity Measurements in Upper St. Clair River}

A detailed velocity survey of the upper 2.5-mile reach of St. Clair River was done jointly by the USGS and the USACE during July 1-3, 2003. Workhorse Rio Grande ADCP units by RD Instruments were used for the survey. ADCP units used in this study emit acoustic signals through four ceramic transducers. The transducers are on the underside of the unit and are oriented downward with a 20-degree offset from the vertical and outward with a 90-degree horizontal angle of separation. Following a signal emission, the four transducers detect reflected signals from backscattering material in the water column. Returning signals are subdivided into a set of time intervals that correspond to small $(25-100 \mathrm{~cm})$ intervals of flow depth. The phase shift in returning signals is used to compute the northing, easting, and vertical velocity components for each depth interval by use of the Doppler principle (Simpson, 2001). A collection of velocity data with depth for each acoustic signal is referred to as a "velocity ensemble."

During the 2003 survey, ADCP units were attached to boats that made single-transect measurements across the river. For each transect, an attempt was made to maintain the boat speed at a rate lower than the local water speed. With acoustic signals typically emitted at twice per second (sampling at $2 \mathrm{~Hz}$ ), this resulted in velocity ensembles at about 1-ft intervals along each transect. Transects were separated by about 100-ft intervals, thus providing 127 single-transect ADCP flow measurements across Upper St. Clair River (figs. 3-6). 

Function of Depth on Upper St. Clair River in the Great Lakes Basin

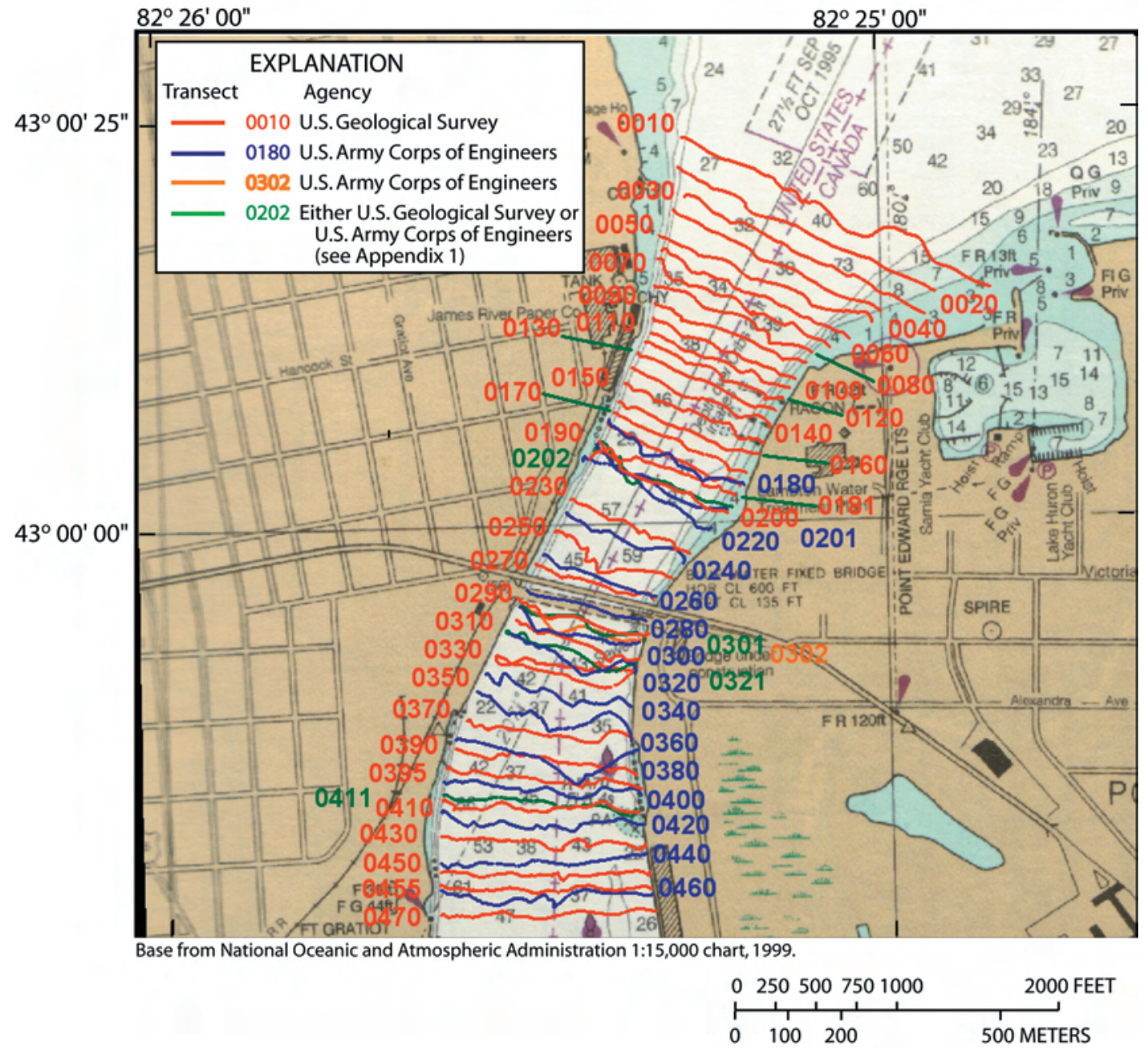

Figure 3. Acoustic Doppler current profiler (ADCP) transects in Upper St. Clair River (panel 1). 
$82^{\circ} 26^{\prime}$

$82^{\circ} 25^{\prime}$

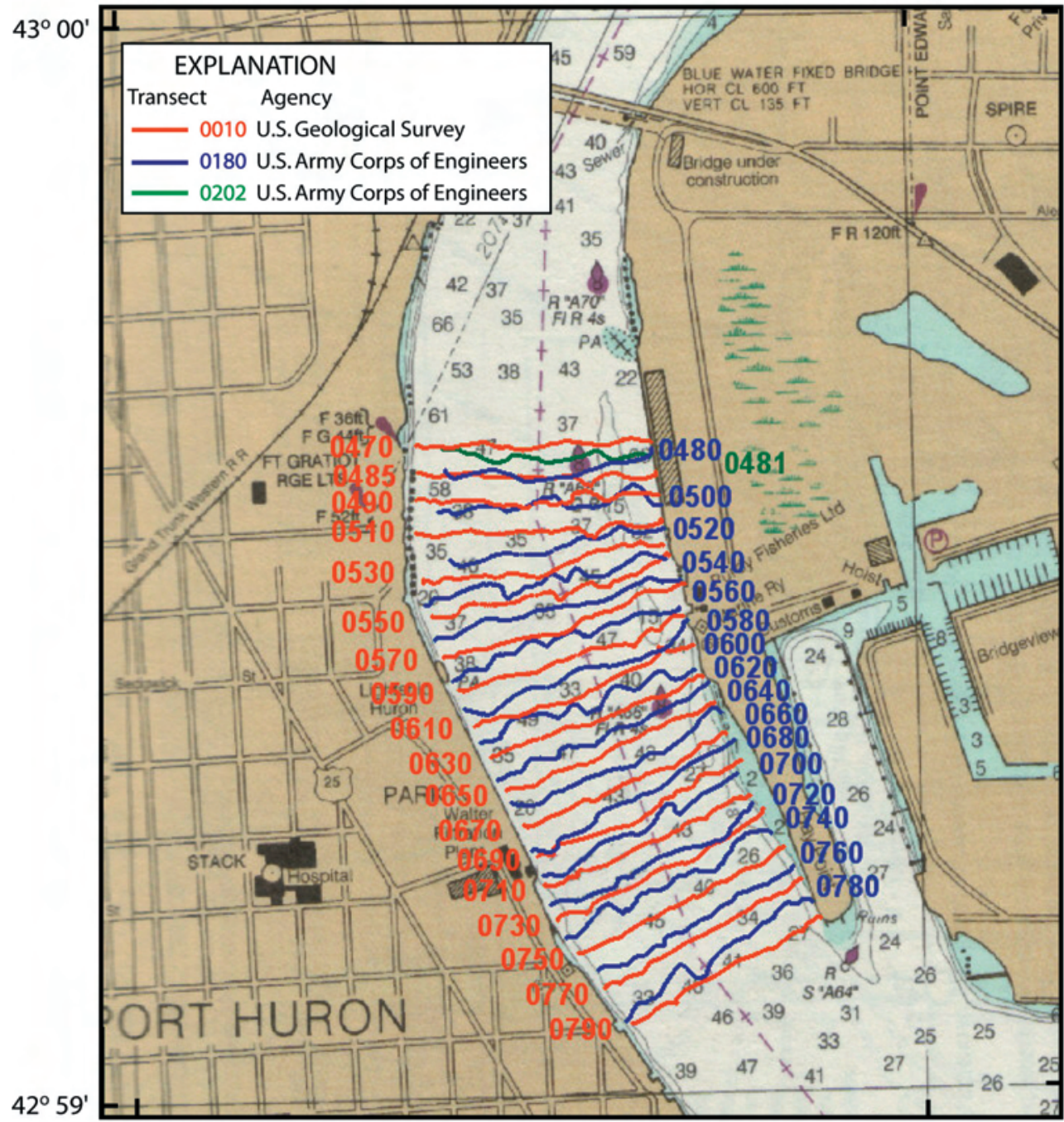

Base from National Oceanic and Atmospheric Administration 1:15,000 chart, 1999.

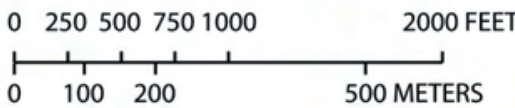

Figure 4. ADCP transects in Upper St. Clair River (panel 2). 


\section{Augementing Two-Dimensional Hydrodynamic Simulations with Measured Velocity Data to Identify Flow Paths as a Function of Depth on Upper St. Clair River in the Great Lakes Basin}

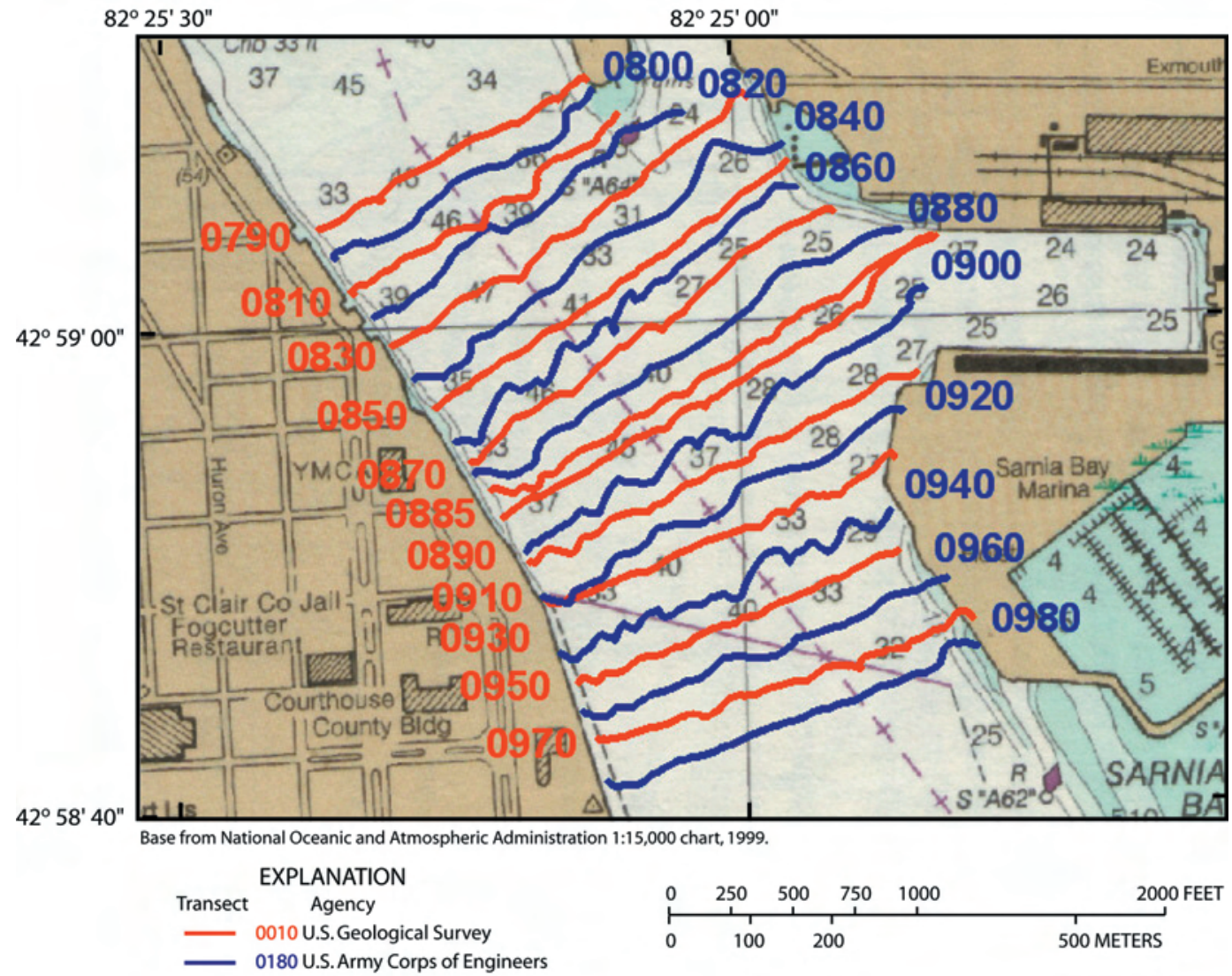

Figure 5. ADCP transects in Upper St. Clair River (panel 3).

The 2.1 million velocity measurements obtained during the survey were subdivided into seven discrete layers corresponding to depth intervals having a thickness of $6.56 \mathrm{ft}(2 \mathrm{~m})$ or more (fig. 7). Among these intervals, the top (first) layer was thicker $(8.4 \mathrm{ft})$ than most other layers because no velocity measurements were available at depths less than $3.4 \mathrm{ft}$ below the water surface. Near-water-surface velocities are lacking because deployed ADCP units were submerged below the water surface by about $1 \mathrm{ft}$. In addition, ADCP measurements require time for vibration of the ceramic transducer plates to dampen sufficiently before detection of incoming signals is possible. This time delay results in a loss of data just below the ADCP unit that is referred to as the blanking distance. The bottom (seventh and deepest) layer also has a thickness greater than $6.56 \mathrm{ft}$ because it contains all velocity measurements greater than $41.2 \mathrm{ft}$ below the water surface. The subdivision of measurements served as a mechanism to detect possible differences in velocity with depth. 
$82^{\circ} 25^{\prime} 00^{\prime \prime}$

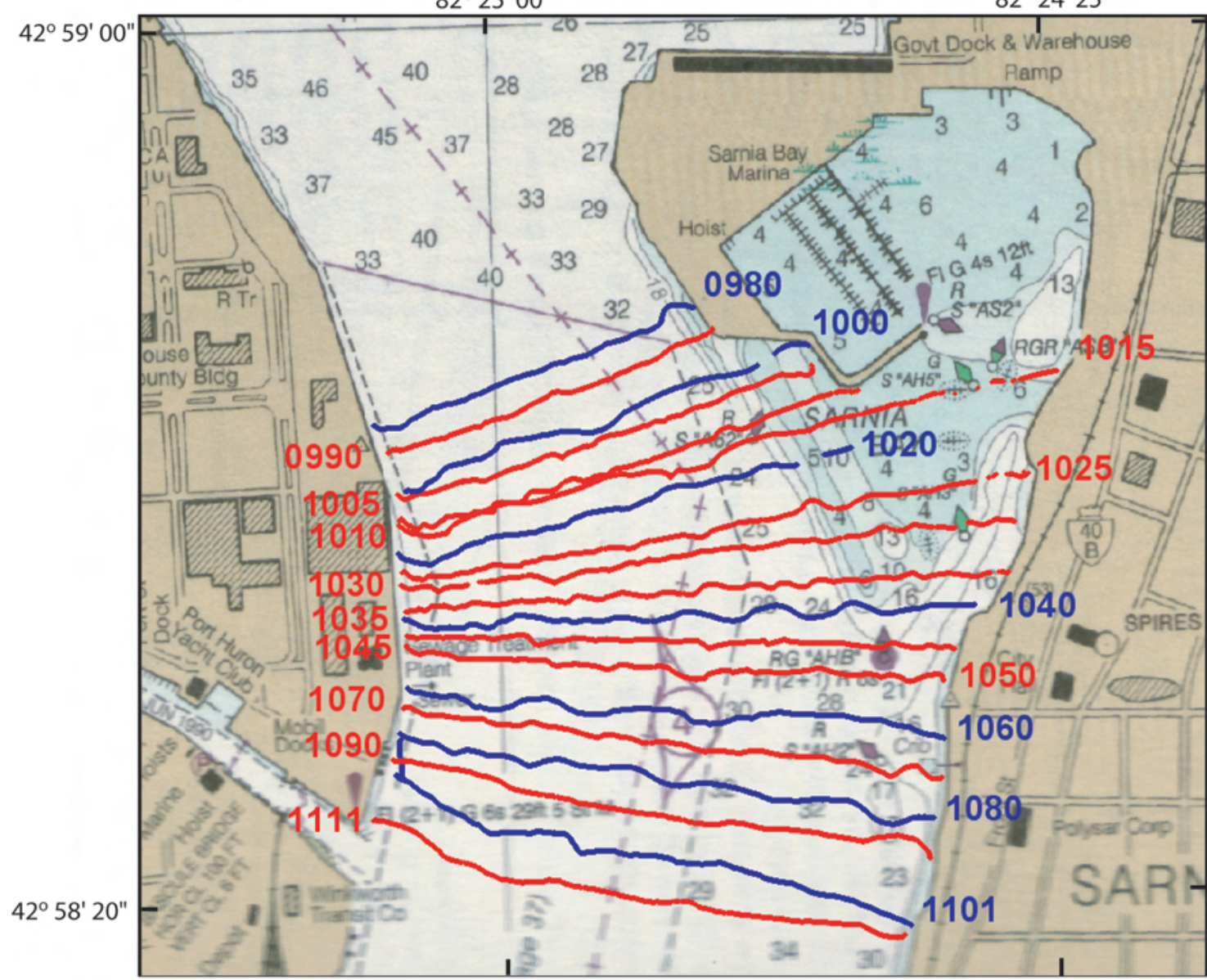

Base from National Oceanic and Atmospheric Administration 1:15,000 chart, 1999.

EXPLANATION

Transect Agency

0010 U.S. Geological Survey

0180 U.S. Army Corps of Engineers

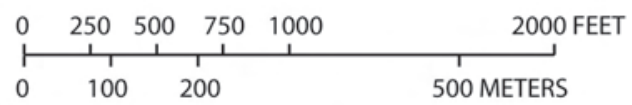

Figure 6. ADCP transects in Upper St. Clair River (panel 4). 


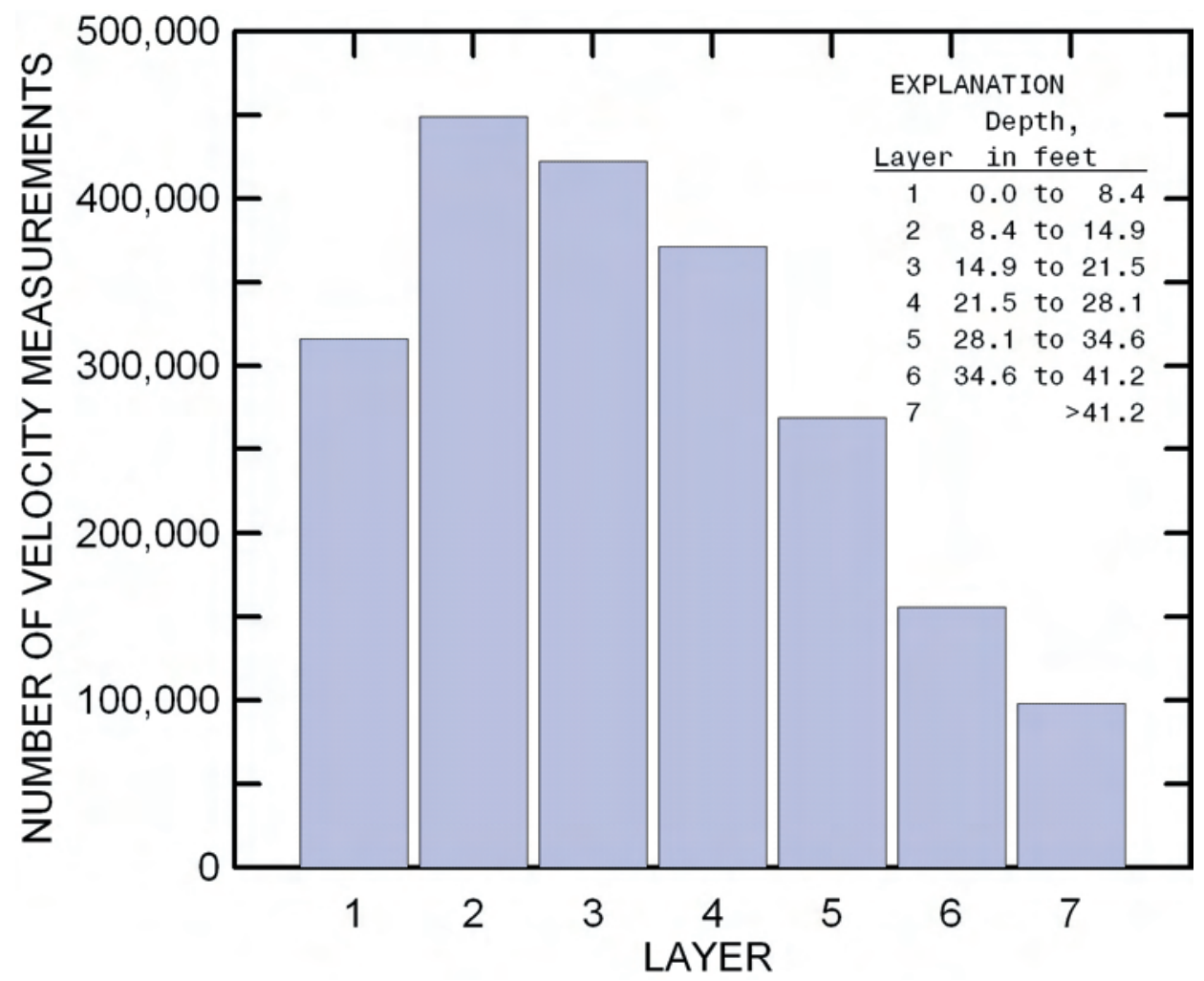

Figure 7. Histogram of velocity measurement distribution by layer during the July 2003 ADCP survey of Upper St. Clair River.

USGS measurements were made using a 600-kHz ADCP unit and a bin size of $1.64 \mathrm{ft}(50 \mathrm{~cm})$. In contrast, USACE measurements were made using a 1200-kHz unit and bin sizes of $0.82 \mathrm{ft}(25 \mathrm{~cm})$ and $3.28 \mathrm{ft}(100 \mathrm{~cm})$. The $600-\mathrm{kHz}$ unit obtained velocity information throughout the deepest water transected during the survey. The $1200-\mathrm{kHz}$ unit was unable to measure some isolated areas where depths of water exceeded $60 \mathrm{ft}$, but could yield higher resolution of velocities (smaller bin sizes) than the 600-kHz unit. Despite minor differences in instrumentation, mounting characteristics, and boats, flow measurements by USGS and USACE crews were consistent (fig. 8). Some measurements that indicate less than expected flows at transects 0480, 0481, 0500, and 0520 may be related to shoreline obstructions, such as docked freighters, which resulted in shortened transects and underestimated flows on the U.S. side of the river. With the exception of these four measurements, the measured flow had a mean of $176,000 \mathrm{ft}^{3} / \mathrm{s}$ and a standard deviation of 3.1 percent. 


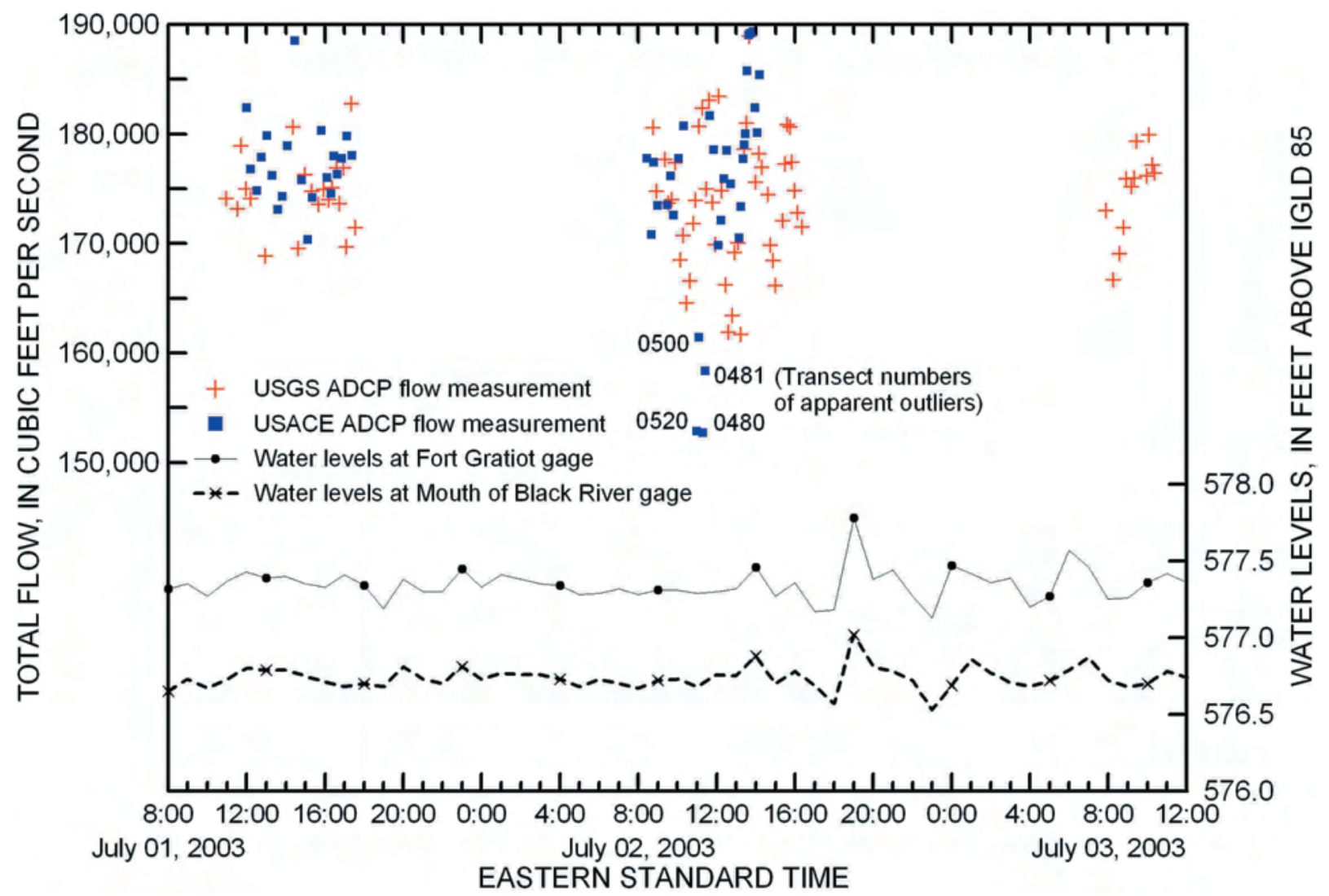

Figure 8. Flows and water levels during the July 2003 ADCP survey of Upper St. Clair River.

\section{Hydrodynamic Simulation of Upper St. Clair River}

The generalized 2D hydrodynamic code RMA2 (Donnell and others, 2003) was applied to the St. Clair-Detroit River Waterway as part of the Michigan Source Water Assessment Program (Holtschlag and Koschik, 2004). The finite-element method is used within RMA2 to solve the continuous equations governing dynamically changing horizontal velocity components and water levels in surface-water bodies. The finite-element method facilitates this solution by discretizing the waterway geometry into a mesh composed of quadrilateral and triangular elements. Elements are defined by corner nodes at the vertices of the elements and by midside nodes midway between vertices.

Hydrodynamic simulations result in predictions of easting $\widetilde{U}_{\text {Node( } x, y)}$ and northing $\widetilde{V}_{\text {Node( } x, y)}$ velocity components and water levels at model nodes based on conditions specified at the boundaries of the waterway, the description of the waterway geometry, and model parameters. Horizontal flow components and water levels elsewhere within the waterway are estimated by quadratic interpolation across elements from the defining nodes. The density of nodes and elements determines the maximum resolution of flow simulations and affects the stability of the numerical solution.

The mesh for the public water intake version of the hydrodynamic model developed for source water assessment of the St. Clair-Detroit River Waterway consisted of 30,306 elements defined by 90,306 nodes (Holtschlag and Koschik, 2004). Within Upper St. Clair River, this mesh contained 1,513 quadratic elements and 42 triangular elements defined by 4,868 nodes. To better simulate the complex flow patterns observed in Upper St. Clair River and to enhance the numerical stability of the solution, the mesh for the public water intake version was refined: each element was subdivided into four subelements, with a corresponding increase in the number of nodes. The resulting mesh, referred to as the "refined mesh" in this report, consists of 6,052 quadrilateral elements and 168 triangular elements defined by 18,981 nodes (fig. 9). Typical elements were $35 \mathrm{ft}$ wide and 120 $\mathrm{ft}$ long, thus having an aspect ratio in the direction of flow of 0.29 . 
Public Water Intake Mesh within Upper St. Clair River

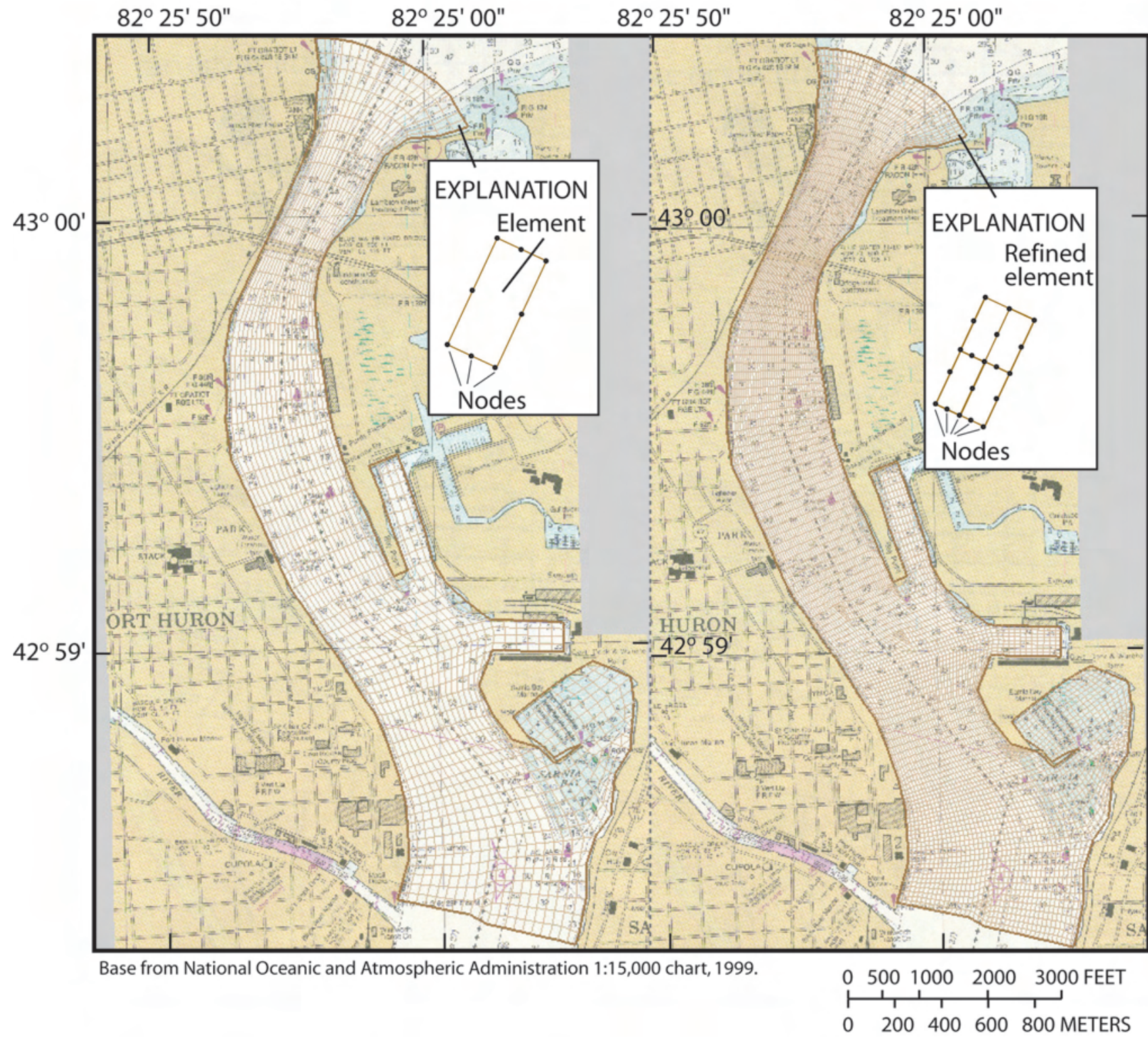

Figure 9. The finite-element mesh for the public water intake version and the refined version of the Upper St. Clair River model. 
In addition to refining the mesh, a numerical procedure termed the "Bendway Correction" was implemented to improve predictions of flow around channel bends. Conventional RMA2 depth-averaged calculations of flow around a bend frequently overestimate streamwise velocities on the inside bank of a river bend (Donnell and others, 2003). When water flows around a bend, a radial acceleration is developed that forces the near-surface waters to the outside bank and the water near the bed to the inside bank. This results in a secondary or helical flow pattern that causes sediment aggradation on the inside of curves and soil erosion on the outside of curves. RMA2 normally cannot simulate this effect accurately. To improve predictions of depthaveraged velocities around curves, a secondary flow corrector, termed the "Bendway Correction," was made available with the release of RMA2 version 4.35 (Donnell and others, 2003).

The Bendway Correction works by solving an additional equation for the transport of streamwise vorticity, where vorticity is a measure of flow rotation. Streamwise vorticity occurs in the vertical plane, perpendicular to the direction of flow, and is related to the radial accelerations that cause helical flow patterns around channel bends (Donnell and others, 2003). To lessen memory requirements for RMA2, the calculation of velocities and depths (phase 1) is separated from the calculation of vorticities (phase 2).

To implement the Bendway Correction in the Upper St. Clair River model, a conventional hydrodynamic solution was obtained before activating the Bendway Correction. Although not activated initially, a BVL card (Donnell and others, 2003) was used to specify a vorticity of zero at the upstream flow boundary. Then, using the REV card (Donnell and others, 2003), the simulation was revised to activate the Bendway Correction by specifications on the VO and TV cards (Donnell and others, 2003). Parameters on the VO card were used to switch the Bendway Correction on, to specify a 0.001 -ft convergence criterion, and to specify vorticity coefficients. Default values for coefficients listed by Donnell and others (2003) were used. The TV card controls the number of iterations for vorticity calculations. In this simulation, the maximum number of iterations between phase 1 and phase 2 computations was set to 100 . The maximum number of phase 2 iterations was set to 100 . Finally, the minimum number of successfully converging passes between phase 1 and phase 2 iterations was set to 10 (Donnell and others, 2003). The hydrodynamic model of Upper St. Clair River was recalibrated to improve the match between measured and simulated velocities. Recalibration was accomplished by adjusting the Peclet number, which automatically assigns eddy viscosities to individual elements. The Peclet formula can be written as

$$
E=\rho \cdot u \cdot d x / P
$$

where $\quad E$ is the eddy viscosity,

$\rho$ is the fluid density,

$u$ is the average elemental velocity,

$d x$ is the length of the element in the streamwise direction, and

$P$ is the Peclet number.

Higher Peclet numbers (lower eddy viscosities) allow simulated velocities to readily change direction. Minimum eddy viscosity values are required, however, to maintain numerical stability. Although it is difficult to theoretically establish a value for Peclet numbers or eddy viscosities, analogy with physical conditions suggests that turbulence exchanges depend on the momentum of the fluid, spatial gradients of the velocity, and the scale of the flow phenomenon, characterized here by length of the element in the streamwise direction (Donnell and others, 2003). Therefore, as the element size or flow velocities increase, eddy viscosity also should increase. The Peclet method automatically adjusts the eddy viscosity after each iteration, on the basis of element sizes and simulated velocities.

\section{Integration of Velocity Measurements With Flow Simulations}

This section describes the procedures used to integrate velocity measurements with simulated flows. Essentially, simulated velocities were estimated at ensemble locations by quadratic interpolation from simulation results at model nodes. Then, the differences between simulation estimates and measured velocities were computed for each model layer at all ensembles. These differences are referred to as "innovations." The spatial coherency of these velocity innovations was described by use of variogram analysis. A measure of this coherency provided a basis for computing the expected innovation across a grid of 20-ft-square cells spanning the model area by use of the kriging equations. The expected velocity innovations at model nodes were estimated by use of bilinear interpolation from this grid. The expected innovations at model nodes were added to simulated flows to form the integrated velocity information for each layer.

The simulated (depth-averaged) easting and northing velocity components were estimated for each ADCP ensemble by quadratic interpolation, $f_{Q}$, using the easting and northing coordinates of the ensemble, Ens $(\mathrm{x}, \mathrm{y})$, and simulated velocities and specified locations at the set of nodes forming the element containing the ensemble, Node(x.,y.). The resulting depth-averaged estimates for the easting and northing velocity components are designated as $\tilde{U}_{\text {Ens }(x, y)}=f_{O} \quad\left(\tilde{U}_{\text {Node }(x, v .)}, \operatorname{Ens}(x, y)\right)$ 


\section{Augementing Two-Dimensional Hydrodynamic Simulations with Measured Velocity Data to Identify Flow Paths as a Function of Depth on Upper St. Clair River in the Great Lakes Basin}

$\tilde{U}_{E n s(x, y)}=f_{Q}\left(\tilde{U}_{\text {Node }(x, y .)}, \operatorname{Ens}(x, y)\right)$ and, $\tilde{V}_{E n s(x, y)}=f_{Q}\left(\tilde{V}_{\text {Node }(x, y .)}, \operatorname{Ens}(x, y)\right)$ respectively.

Easting and northing velocity components measured in bins of 0.25 - to $1.00-\mathrm{m}$ heights throughout most of the water column were averaged within their nominal 2-m layers (XTable 1X) and designated as $\bar{u}_{E n s(x, y), l}$ and $\bar{v}_{E n s(x, y), l}$. Finally, velocity innovations were defined as the differences between average measured velocities in each layer and simulated velocities as $v_{E n s(x, y), l}=\bar{u}_{E n s(x, y), l}-\tilde{U}_{E n s(x, y)}$. and $v_{E n s(x, y), l}=\bar{v}_{E n s(x, y), l}-\tilde{V}_{E n s(x, y)}$.

Variogram analyses were used to characterize a measure of the spatial correlation structure of the velocity innovations as a function of separation distance, $\mathrm{h}$; this correlation measure is referred to as the variogram and is denoted $\mathrm{g}(\mathrm{h})$. Easting innovations were analyzed independently from northing innovations. Preliminary analysis of vertical velocity components indicated that they were highly variable and contained no appreciable spatial correlation structure. Therefore, only horizontal velocity components are evaluated in this report.

Table 1. Distribution of acoustic Doppler current profiler velocity innovations among layers.

\begin{tabular}{|c|c|c|c|c|c|c|c|}
\hline \multirow[t]{2}{*}{$\begin{array}{l}\text { Layer } \\
\text { number }\end{array}$} & \multirow{2}{*}{$\begin{array}{l}\text { Depth } \\
\text { range of } \\
\text { layer (feet) }\end{array}$} & \multirow{2}{*}{$\begin{array}{l}\text { Number } \\
\text { of velocity } \\
\text { measure- } \\
\text { ments in } \\
\text { laver }\end{array}$} & \multirow{2}{*}{$\begin{array}{l}\text { Number of } \\
\text { depth-averaged } \\
\text { velocity } \\
\text { measurements }\end{array}$} & \multicolumn{2}{|c|}{$\begin{array}{l}\text { Easting velocity innovation } \\
\text { (feet per second) }\end{array}$} & \multicolumn{2}{|c|}{$\begin{array}{l}\text { Northing velocity innovation } \\
\text { (feet per second) }\end{array}$} \\
\hline & & & & Mean & $\begin{array}{l}\text { Standard } \\
\text { deviation }\end{array}$ & Mean & $\begin{array}{l}\text { Standard } \\
\text { deviation }\end{array}$ \\
\hline 1 & $<8.38$ & 315,993 & 134,357 & 0.0719 & 0.6824 & -0.2838 & 0.9109 \\
\hline 2 & $8.38-14.9$ & 449,134 & 131,720 & .0594 & .6413 & -.2144 & .8704 \\
\hline 3 & $14.9-21.5$ & 422,182 & 124,485 & .0236 & .6492 & -.1588 & .8506 \\
\hline 4 & $21.5-28.1$ & 371,164 & 112,051 & -.0130 & .6651 & -.0772 & .8078 \\
\hline 5 & $28.1-34.6$ & 269,060 & 85,352 & -.0203 & .7119 & .0652 & .8271 \\
\hline 6 & $34.6-41.2$ & 155,688 & 50,505 & -.0130 & .7429 & .2422 & .8718 \\
\hline 7 & $>41.2$ & 98,233 & 19,622 & .0783 & .8263 & .5579 & .9681 \\
\hline
\end{tabular}

In this report, Euclidian separation distances were computed for all possible pairs of innovations on the basis of ensemble locations. Separation distances were subdivided into bins having a width of $2 \mathrm{ft}$, up to a maximum separation distance of 300 $\mathrm{ft}$. Thus, all ensembles that were separated by less than $2 \mathrm{ft}$ were placed in the first bin; ensembles with separation distances of 2 to $4 \mathrm{ft}$ were placed in the second bin, and so on, until the 150th bin containing the maximum separation distances of 298 to $300 \mathrm{ft}$ was formed. For each separation bin shown on the x-axis, the mean value of one-half the squared differences between all innovation pairs is plotted on the y-axis as the empirical (semi) variogram, $\gamma(h)$ (fig. 10). 

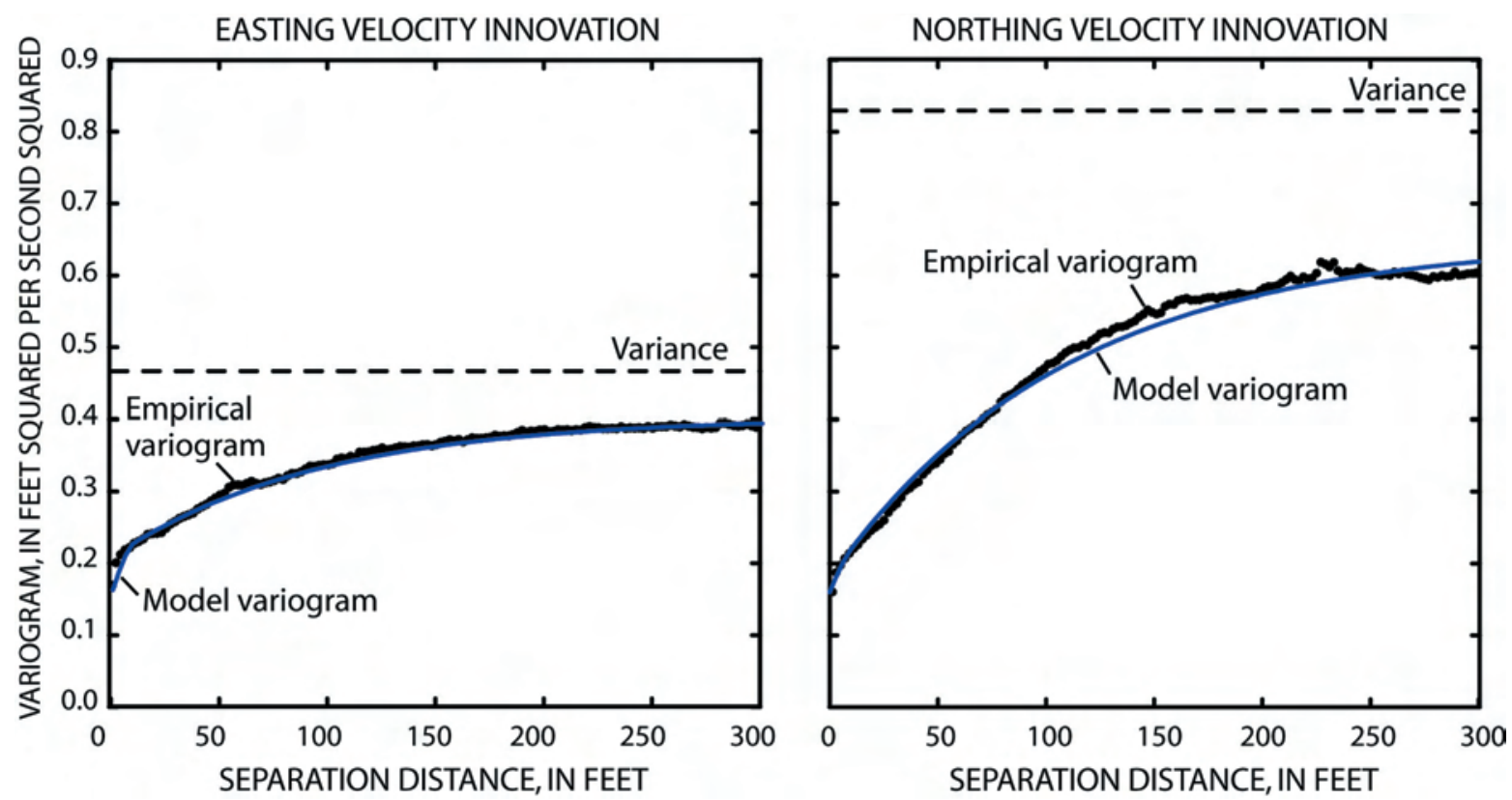

Figure 10. Variogram showing spatial structure of horizontal velocity innovations in layer 1.

The empirical variograms show a generally increasing magnitude from 0 to $300 \mathrm{ft}$ of separation distance. The rate of increase, however, generally decreases with increasing separation distance until the variograms appear to approach an asymptotic limit, or sill, that is less than the variance of the variogram. This indicates that the velocity innovations are consistent with the hypothesis of intrinsic stationarity (de Marsily, 1986), which is assumed in the subsequent application of the kriging equations for estimating expected innovations.

The empirical variogram is approximated by model variograms to provide a mathematically useful form for estimating expected innovations. In this report, a set of three nested variogram models was fit to the empirical variograms for use in estimation, such that the model variogram $\tilde{\gamma}(h)$ was equal to ${ }_{N}(h)+\gamma_{S}(h)+\gamma_{E}(h)$, where, $\gamma_{N}(h)=C_{N}$ is a nugget model component, $\gamma_{S}(h)$ is a spherical model component (equation 2), and $\gamma_{E}(h)$ is an exponential model component (equation 3 ). All variogram models were assumed to be isotropic.

$$
\begin{gathered}
\gamma_{S}(h)=\left\{\begin{array}{c}
C_{S}\left[1.5 h / L_{S}-0.5 \cdot\left(h / L_{S}\right)^{3}\right] \text { for } h<L_{S} \\
C_{S} \text { otherwise }
\end{array}\right\} \\
\gamma_{S}(h)=C_{E}\left[1-e^{-h / L_{E}}\right]
\end{gathered}
$$

The estimated parameters of all variogram models, $C_{N}, C_{S}, L_{S}, C_{E}$, and $L_{E}$ are shown in table 2. 


\section{Augementing Two-Dimensional Hydrodynamic Simulations with Measured Velocity Data to Identify Flow Paths as a Function of Depth on Upper St. Clair River in the Great Lakes Basin}

Results of variogram analyses were used to solve the point kriging equations, which provide the best linear unbiased estimates (de Marsily, 1986) of velocity innovations. In an area containing $n$ ensembles where velocity innovations have been computed near a target point indexed by 0 , the point kriging equations can be written as

$$
\left(\begin{array}{llllll}
0 & \tilde{\gamma}_{12} & \tilde{\gamma}_{13} & \ldots & \tilde{\gamma}_{1 n} & 1 \\
\tilde{\gamma}_{21} & 0 & \tilde{\gamma}_{23} & \ldots & \tilde{\gamma}_{2 n} & 1 \\
\vdots & \vdots & \vdots & \ddots & \vdots & \vdots \\
\tilde{\gamma}_{n 1} & \tilde{\gamma}_{n 2} & \tilde{\gamma}_{n 3} & \ldots & 0 & 1 \\
1 & 1 & 1 & \ldots & 1 & 0
\end{array}\right)\left(\begin{array}{l}
\lambda_{0}^{1} \\
\lambda_{0}^{2} \\
\vdots \\
\lambda_{0}^{n} \\
\mu
\end{array}\right)=\left(\begin{array}{c}
\tilde{\gamma}_{10} \\
\tilde{\gamma}_{20} \\
\vdots \\
\tilde{\gamma}_{n 0} \\
1
\end{array}\right),
$$

where, $\tilde{\gamma}_{12}$, for example, is the magnitude of the model variogram between velocity measurements indexed by 1 and 2 . Similarly, $\widetilde{\gamma}_{10}$, represents the model variogram between sample point 1 and target point 0 . The $\lambda^{\prime}$ s are weights applied to nearby velocity innovations to compute a local average, and $\mu$ is a Lagrange multiplier that constrains the sum of the $\lambda$ 's to 1 . An estimate of the easting innovation magnitude at target point zero based on the nearest $\mathrm{n}$ easting innovations is

$$
\hat{\mathrm{v}}_{x_{0}, y_{0}, l}=\sum_{i=1}^{n} \lambda_{0}^{i} \cdot \mathrm{v}_{x, y, l}
$$

Estimates of northing innovations are computed similarly.

The shape of the variograms (fig. 10), which is inversely related to the weights, indicates that the weights would generally decrease with separation distance from about 0 to $250 \mathrm{ft}$. Beyond $250 \mathrm{ft}$, which is considered the range of the variogram, all innovations would be weighted the same. This range was anticipated from analysis of previous ADCP data on St. Clair River and was used to design the 2003 ADCP survey so that the transect interval would be about $100 \mathrm{ft}$. When estimating the expected innovation from a network of sample points, the geometric configuration of ensemble locations relative to the point of estimation also will affect the weighting factors.

In this report, block kriging (de Marsily, 1986) was used to map the expected value of the easting velocity innovation, $\mathrm{E}[\mathrm{v} \mid \bar{x}, \bar{y}, l]$, and the northing velocity innovation, $\mathrm{E}[\mathrm{v} \mid \bar{x}, \bar{y}, l]$, at the center of each 20 -ft-square cell within a 282-row by 633-column grid spanning the model area. In block kriging, a 3-by-3 array of equally spaced points is targeted for each cell. The average of the nine point-kriging estimates is used to represent the block (cell) average. The maximum search radius used in kriging was $300 \mathrm{ft}$. The minimum easting of the grid was 13,642,100 ft (MSPC 83, southern zone, Int. ft.), and the minimum northing of the grid was 542,410 (MSPC 83, southern zone Int. ft). 
Table 2. Parameters used in model variograms of velocity innovations.

\begin{tabular}{|c|c|c|c|c|c|c|c|c|}
\hline \multirow[t]{3}{*}{ Layer } & \multirow{3}{*}{$\begin{array}{l}\text { Depth } \\
\text { range } \\
\text { (feet) }\end{array}$} & \multirow{3}{*}{$\begin{array}{l}\text { Velocity } \\
\text { innovation } \\
\text { component }\end{array}$} & \multicolumn{6}{|c|}{ Variogram model parameters } \\
\hline & & & \multirow[t]{2}{*}{$\begin{array}{l}\text { Nugget } \\
\left(C_{N}\right)\end{array}$} & $\begin{array}{c}\text { Spherical } \\
\text { model }\end{array}$ & \multicolumn{3}{|c|}{$\begin{array}{l}\text { Exponential } \\
\text { model }\end{array}$} & \multirow{2}{*}{$\begin{array}{l}\text { Variance (feet } \\
\text { squared } \\
\text { per second } \\
\text { squared) }\end{array}$} \\
\hline & & & & $\begin{array}{c}\text { Scale } \\
\left(C_{S}\right)\end{array}$ & $\begin{array}{l}\text { Length } \\
\left(L_{S}\right)\end{array}$ & $\begin{array}{l}\text { Scale } \\
\left(C_{E}\right)\end{array}$ & $\begin{array}{l}\text { Length } \\
\left(L_{E}\right)\end{array}$ & \\
\hline \multirow[t]{2}{*}{1} & \multirow[t]{2}{*}{$<8.38$} & Easting & 0.175 & 0.045 & 10 & 0.185 & 95 & 0.466 \\
\hline & & Northing & .160 & .020 & 10 & .470 & 110 & .830 \\
\hline \multirow[t]{2}{*}{2} & \multirow{2}{*}{$\begin{array}{r}8.38- \\
14.9\end{array}$} & Easting & .130 & .070 & 10 & .170 & 110 & .411 \\
\hline & & Northing & 120 & .040 & 10 & 420 & 100 & .758 \\
\hline \multirow[t]{2}{*}{3} & \multirow{2}{*}{$\begin{array}{r}14.9- \\
21.5\end{array}$} & Easting & .140 & .090 & 12 & .140 & 90 & .421 \\
\hline & & Northing & .125 & .040 & 10 & .400 & 85 & .724 \\
\hline \multirow[t]{2}{*}{4} & \multirow{2}{*}{$\begin{array}{r}21.5- \\
28.1\end{array}$} & Easting & .160 & .110 & 10 & .130 & 100 & .442 \\
\hline & & Northing & .154 & .050 & 14 & .350 & 90 & .653 \\
\hline \multirow[t]{2}{*}{5} & \multirow{2}{*}{$\begin{array}{r}28.1- \\
34.6\end{array}$} & Easting & .210 & .120 & 10 & .130 & 120 & .507 \\
\hline & & Northing & .190 & .075 & 10 & .310 & 70 & .684 \\
\hline \multirow[t]{2}{*}{6} & \multirow{2}{*}{$\begin{array}{r}34.6- \\
41.2\end{array}$} & Easting & .235 & .120 & 12 & .140 & 100 & .552 \\
\hline & & Northing & .205 & .080 & 10 & .330 & 60 & .760 \\
\hline \multirow[t]{2}{*}{7} & \multirow[t]{2}{*}{$>41.2$} & Easting & .290 & .150 & 20 & .200 & 100 & .683 \\
\hline & & Northing & .270 & .120 & 10 & .490 & 90 & .937 \\
\hline
\end{tabular}

\section{Results}

\section{Velocity Survey}

During the July 2003 ADCP survey of Upper St. Clair River, 2,100,954 measurements of velocity were obtained. Easting velocities generally (98 percent of the time) ranged from -4.1 to $3.3 \mathrm{ft} / \mathrm{s}$, where negative velocities indicate a westerly direction (fig. 11). Similarly, northing velocities generally ranged from -6.9 to $1.3 \mathrm{ft} / \mathrm{s}$. Resultant speeds generally ranged from 0.3 to $7.3 \mathrm{ft} / \mathrm{s}$. In contrast to the predominantly southerly flow direction, northerly velocities occurred along the Canadian shoreline near a large eddy that was about $1,800 \mathrm{ft}$ downstream from the Blue Water Bridge near the waterfront building (fig. 2). The eddy, which circulated counterclockwise, was approximately $450 \mathrm{ft}$ wide and 1,000 ft long. 


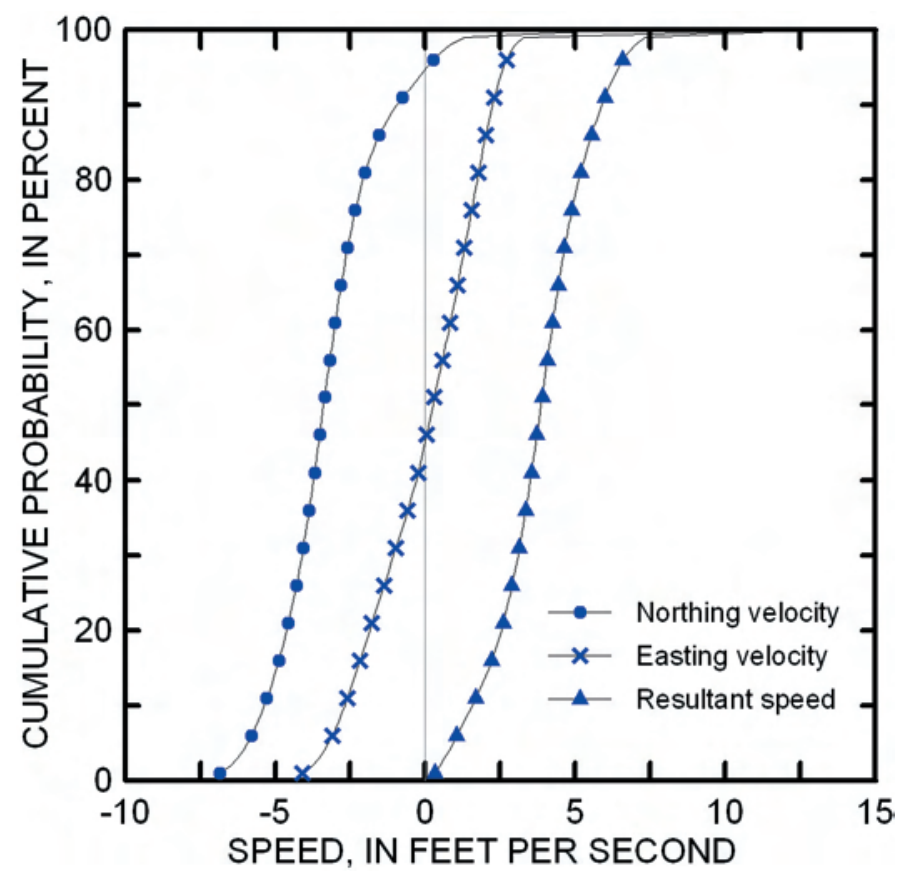

Figure 11. Cumulative distribution function of flow velocities measured during the July 2003 ADCP survey of Upper St. Clair River.

Ninety-nine percent $(2,081,454)$ of the 2003 ADCP velocity survey measurements were located within the finite-element mesh of the hydrodynamic model. Among the elements forming the mesh, about 35 percent $(2,175$ of 6,220$)$ had no ADCP measurements, 50 percent had 240 or more measurements, 25 percent had 497 or more measurements, and 10 percent had 826 or more measurements. Element-averaged velocities are used subsequently to compare measured and simulated results.

\section{Model Enhancements}

As mentioned previously, a subreach of the public water intake version of hydrodynamic model of the St. Clair-Detroit River Waterway (Holtschlag and Koschik, 2004) was enhanced to improve identification of flow paths near public water intakes operated by the city of Port Huron, Michigan. The subreach, referred to as Upper St. Clair River, was enhanced by (1) refining the finite-element mesh to provide additional detail on the local flow conditions and greater numerical stability, (2) implementing the Bendway Correction for improved flow simulations around channel bends, and (3) recalibrating the model on the basis of velocity data obtained during the July 2003 ADCP survey. The following sections describe the results of these enhancements.

\section{Mesh Refinement}

In Upper St. Clair River, mesh refinement quadrupled the number of elements to 6,220 and increased the number of nodes to 18,981 with respect to the public water intake version of the hydrodynamic model developed for the Source Water Assessment Program. The additional nodes provide more points for velocity and water-level simulation, thus increasing the resolution of flow information. Simulation results at individual nodes common to both model versions, however, were expected to produce generally consistent results. 
To verify the consistency of simulation results between the two model versions, both versions were simulated by use of steady-state boundary specifications that approximated conditions during the July 2003 ADCP survey. The average measured flow of $175,128 \mathrm{ft}^{3} / \mathrm{s}$ was specified as the upstream boundary at the head of St. Clair River near the Fort Gratiot, Mich., gaging station. An average measured water level of $576.739 \mathrm{ft}$ was specified as the downstream boundary on Upper St. Clair River, based on records at the Mouth of the Black River, Mich. gaging station. No wind boundary conditions were specified.

Simulated flow velocities and water levels by the two model versions were in close agreement (figs. 12-14). Minor discrepancies may be related to greater flow resolution in the refined mesh and variability due to the precision specified for numerical convergence. Velocity patterns on Upper St. Clair River downstream from the Blue Water Bridge simulated by use of the refined mesh (XFigure 15X) are consistent with those simulated by use of the mesh developed for the public water intake version, given that they are simulated with the same numerical options (no Bendway Correction) and parameterization (same Peclet number). The large eddy structure identified during the July 2003 ADCP survey was not reproduced by either version.

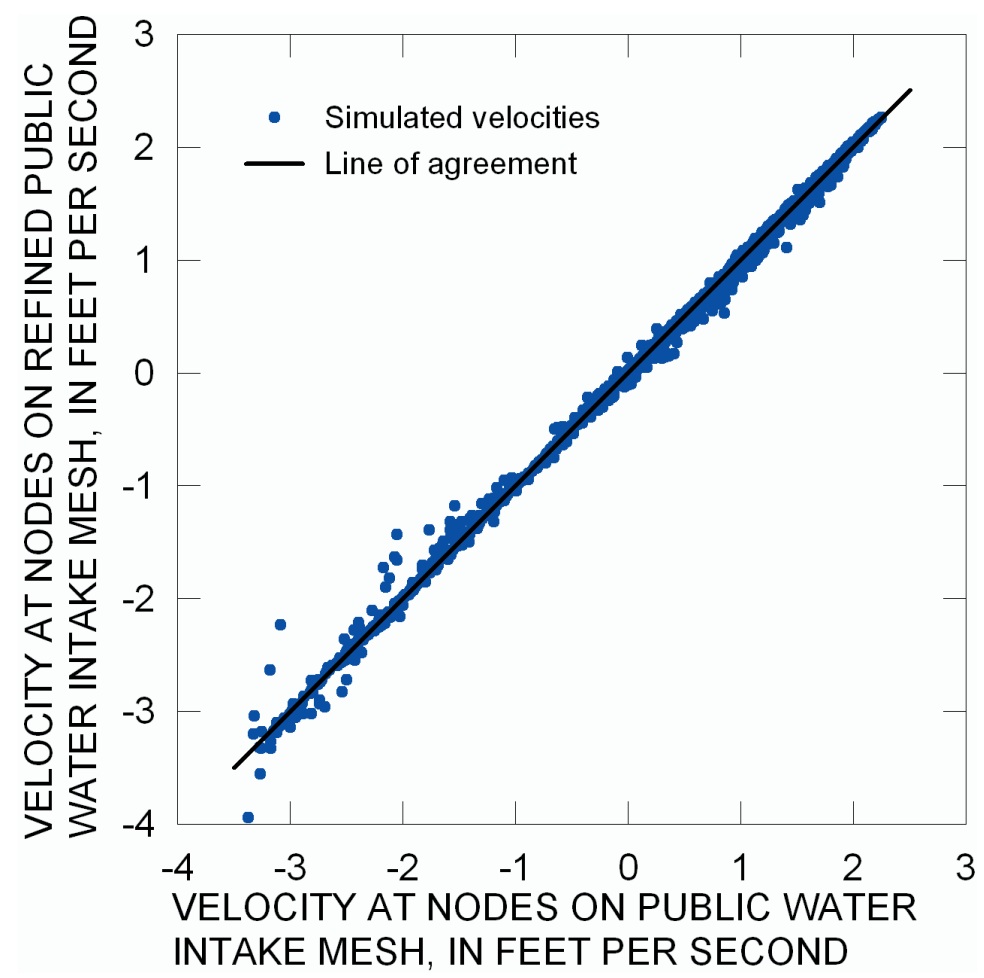

Figure 12. Relation between easting velocity components simulated by the public water intake version and the refined version of the Upper St. Clair River hydrodynamic model. 


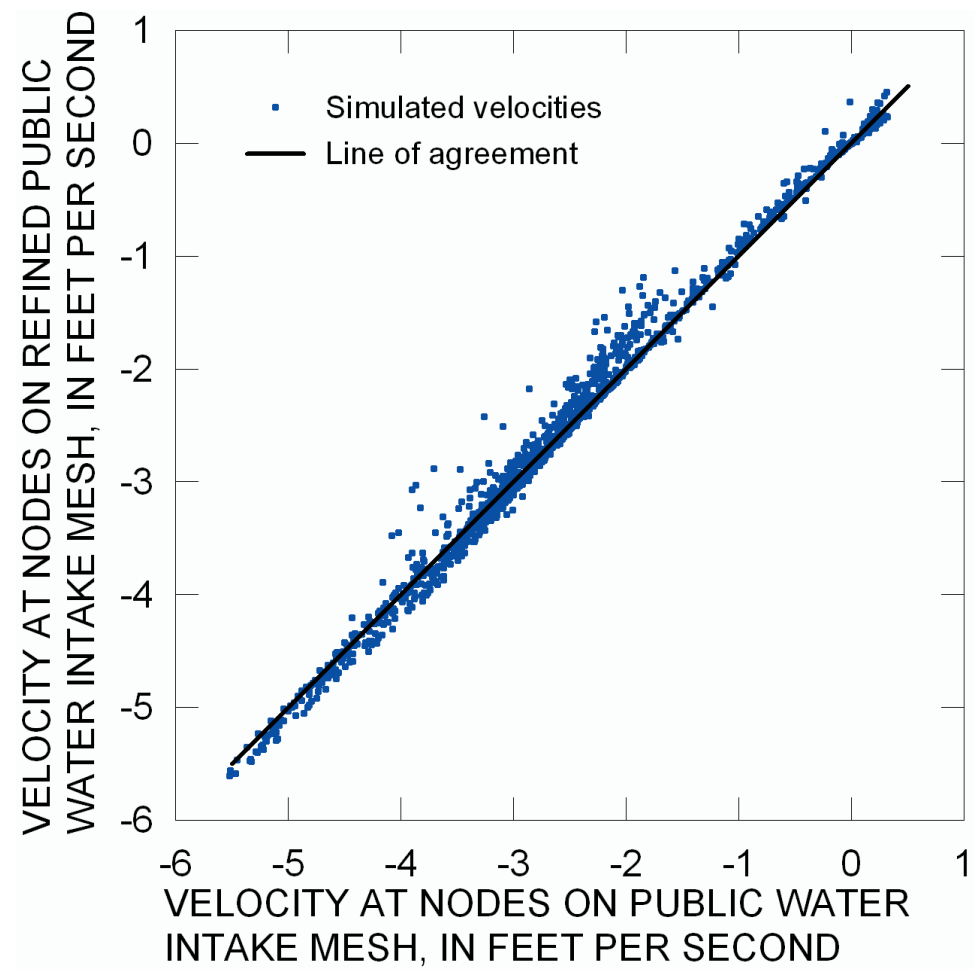

Figure 13. Relation between northing velocity components simulated by the public water intake version and the refined version of the Upper St. Clair River hydrodynamic model.

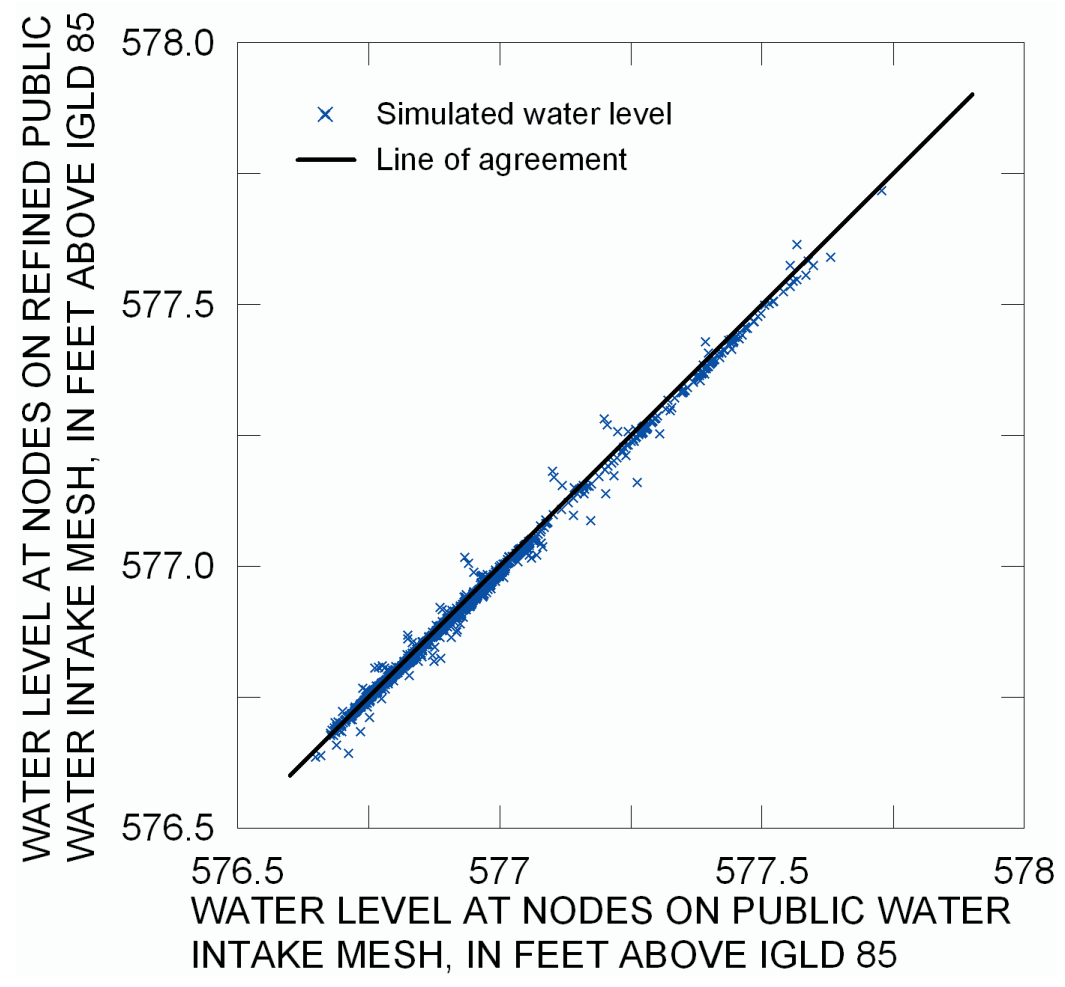

Figure 14. Relation between water levels simulated by the public water intake version and the refined version of the Upper St. Clair River hydrodynamic model. 


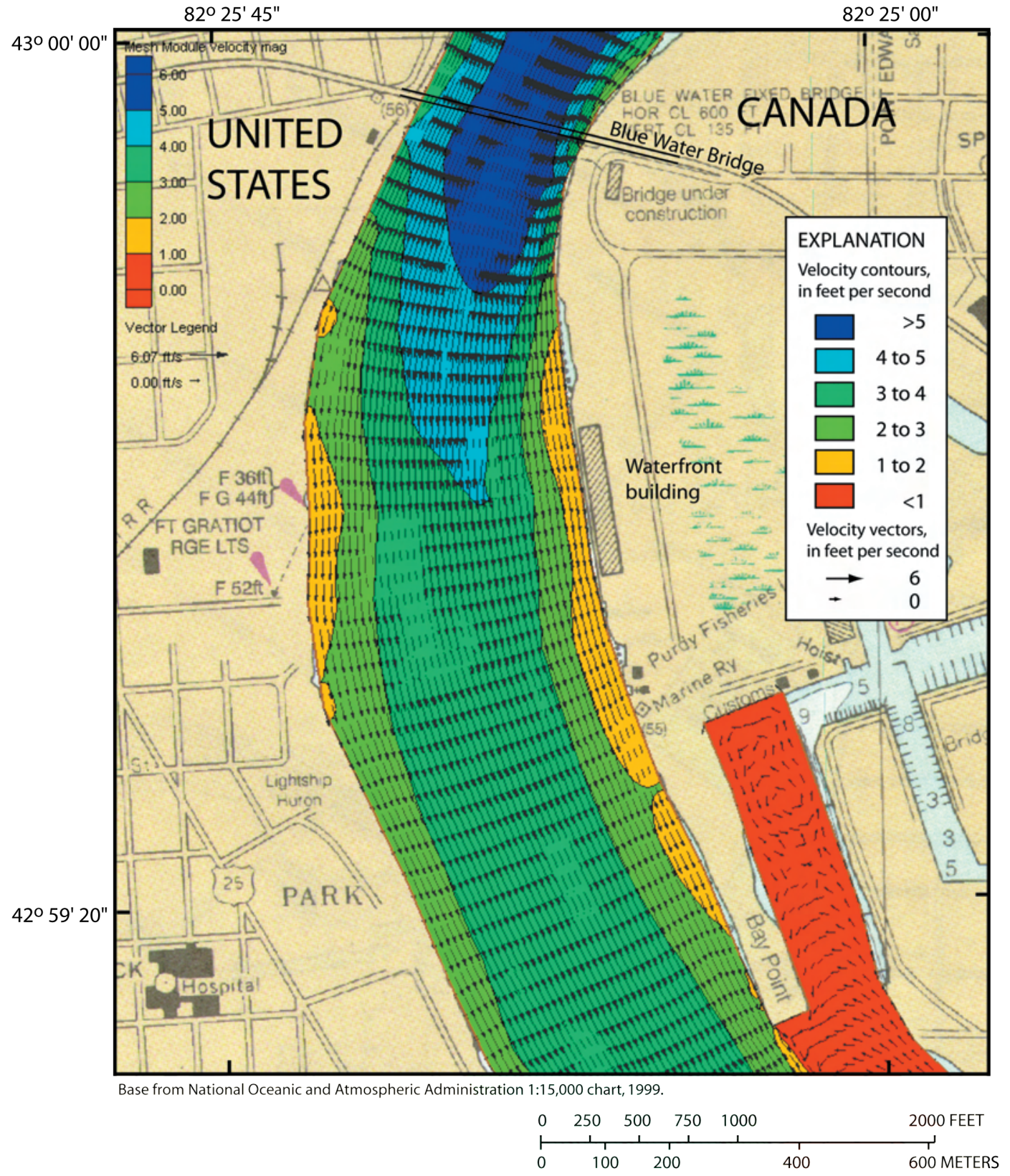

Figure 15. Simulated velocities downstream from the Blue Water Bridge on Upper St. Clair River using the refined mesh without the Bendway Correction and with a Peclet number of 21.9. 


\section{Augementing Two-Dimensional Hydrodynamic Simulations with Measured Velocity Data to Identify Flow Paths as a Function of Depth on Upper St. Clair River in the Great Lakes Basin}

\section{Bendway Correction}

Implementation of the Bendway Correction results in the simulation of vorticity at all model nodes. For a Peclet number of 21.9 and boundary specifications representing flow and water-level conditions during the 2003 ADCP survey, results show that the vorticity simulated with the refined mesh is uniform and of relatively low magnitude near the waterfront building along the Canadian shoreline (fig. 16). Local variations in simulated vorticity near the flow boundary specifications may be related to local irregularities in the defined shoreline geometry.

Significant changes in the pattern of simulated velocities, however, result from implementation of the Bendway Correction for boundary conditions prevalent during the July 2003 ADCP survey. In particular, simulated velocities generally decreased along the inside bank of Upper St. Clair River downstream from the Blue Water Bridge near the waterfront building (fig. 17). Correspondingly, simulated velocities generally increased along the outside of the bank along the U.S. shoreline. Although the pattern of velocity changes is significant, the magnitudes of these changes do not account for most of the discrepancies between simulated and measured velocities. Donnell and others (2003) suggest that the Bendway Correction makes little difference where helical flows have fully evolved a shallow point bar on the inside bank and a deep channel on the outer bank. This channel geomorphology is evident in figure 2 .

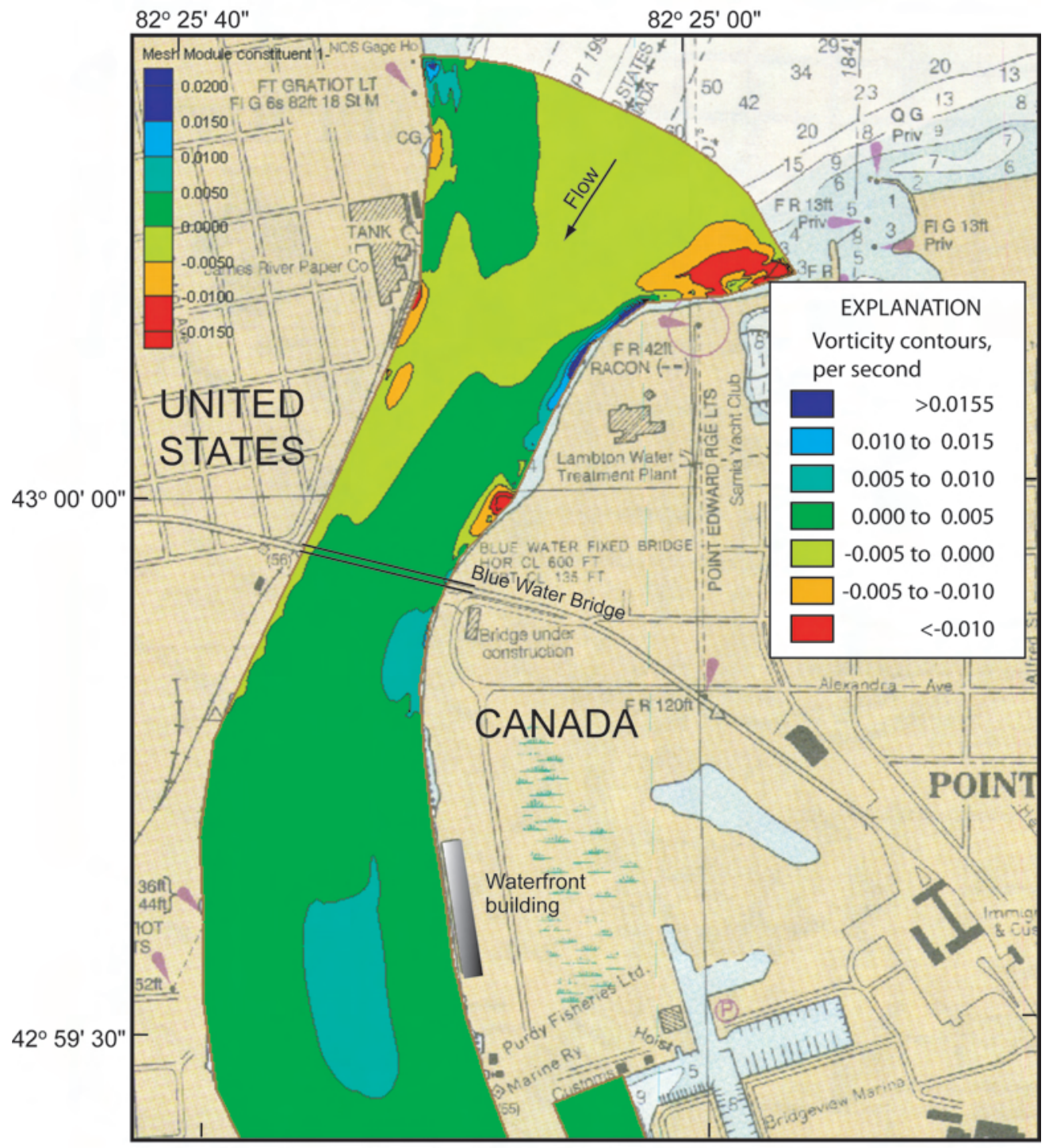

Base from National Oceanic and Atmospheric Administration 1:15,000 chart, 1999.

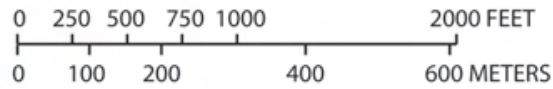

Figure 16. Simulated vorticity in the northern part of Upper St. Clair River. 


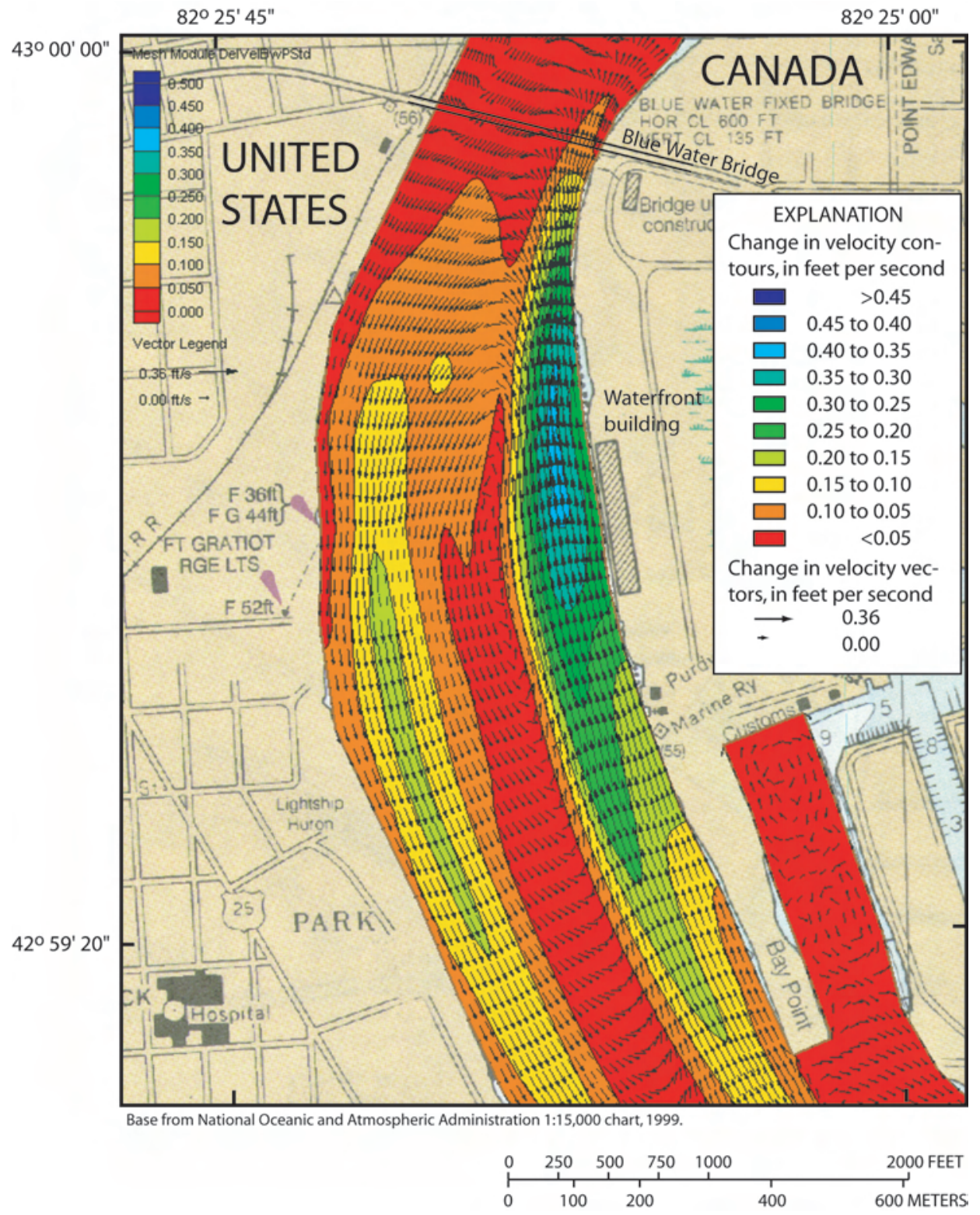

Figure 17. Change in velocities simulated by use of the refined mesh with implementation of the Bendway Correction and a Peclet number of 21.9. 


\section{Augementing Two-Dimensional Hydrodynamic Simulations with Measured Velocity Data to Identify Flow Paths as a Function of Depth on Upper St. Clair River in the Great Lakes Basin}

\section{Peclet Number}

A Peclet number of 21.9 was estimated for the hydrodynamic model representing the St. Clair-Detroit River Waterway (Holtschlag and Koschik, 2004) based on 2002 ADCP surveys of St. Clair River (Holtschlag and Koschik, 2003a) and Detroit River (Holtschlag and Koschik, 2003b). This value was determined on the basis of parameter estimation techniques and fell within the range of 15 to 40 commonly used for Peclet numbers (Donnell and others, 2003). Although perhaps the best single value for the entire waterway, this parameterization did not enable the model to simulate the large eddy measured on Upper St. Clair River near the waterfront building along the Canadian shoreline. Increases in the Peclet number were used to better reproduce the large variability in velocities measured within Upper St. Clair River.

A series of model simulations were done with the refined mesh and Bendway Correction under boundary specifications consistent with conditions on the Upper St. Clair River model during the 2003 ADCP survey. The series was initiated with a Peclet number of 21.9, and computations were revised by step increases to 210, where simulations failed to converge. A Peclet number of 200, which was near the maximum value needed to ensure numerical stability, was used.

To assess the improvement in velocity matching, ADCP measurements were located within their corresponding model elements. Average measured easting and northing velocities were computed for each element. In addition, the average simulated velocities were computed for each element by quadratic interpolation of simulated velocities at ADCP measurement locations. The match between element-averaged measured and simulated velocities increased with increasing Peclet number. The best match in velocities occurred at a Peclet number of 200 (fig. 18), with greater improvements in the match between measured and simulated northing velocity components than for easting components. Resulting simulations using a Peclet number of 200 show further decreases in northing velocities near the waterfront building, with some areas of reverse flow appearing (fig. 19).
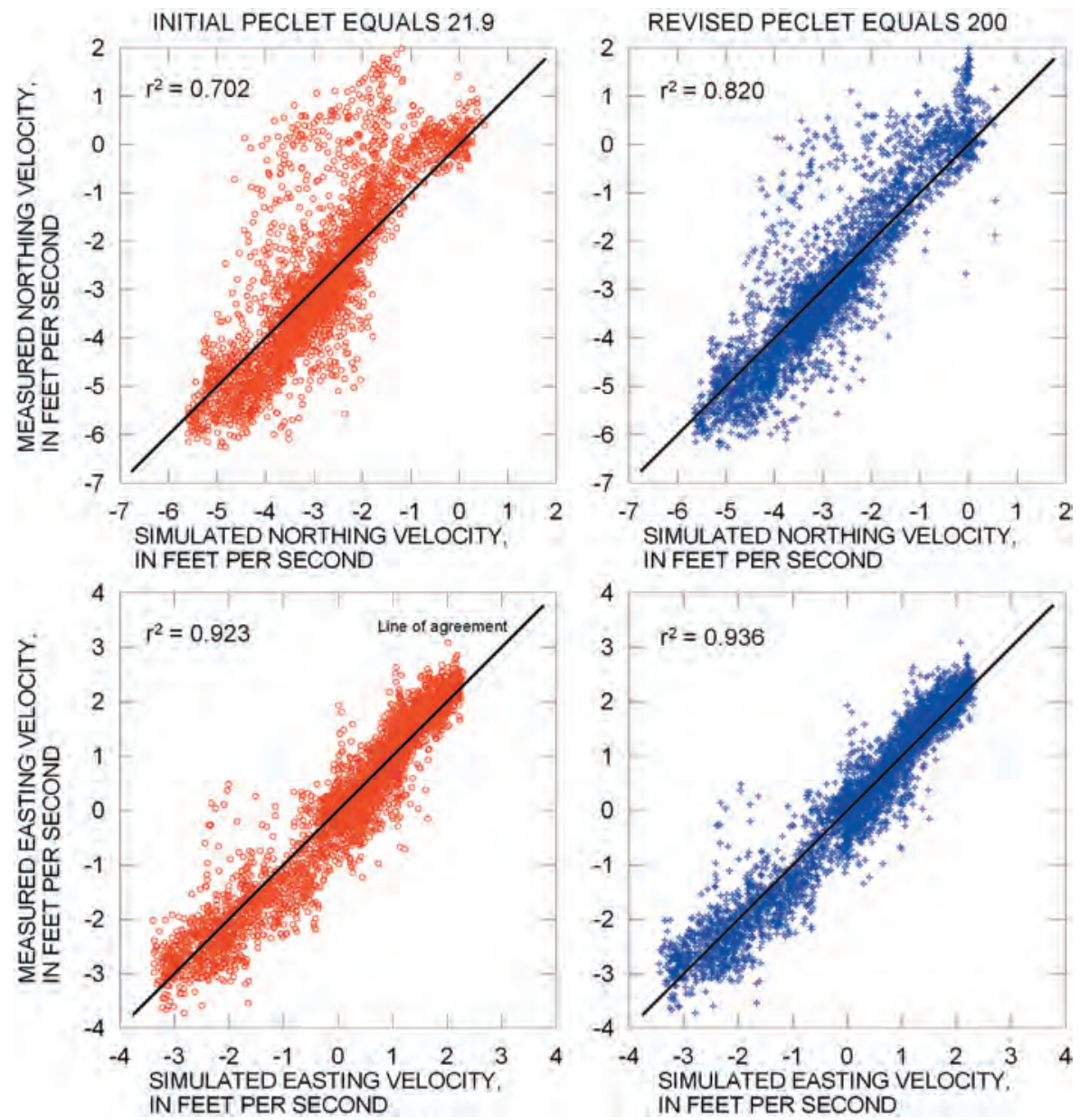

Figure 18. Relation between simulated and measured velocities averaged within elements for the initial Peclet number of 21.9 and the revised Peclet number of 200. 


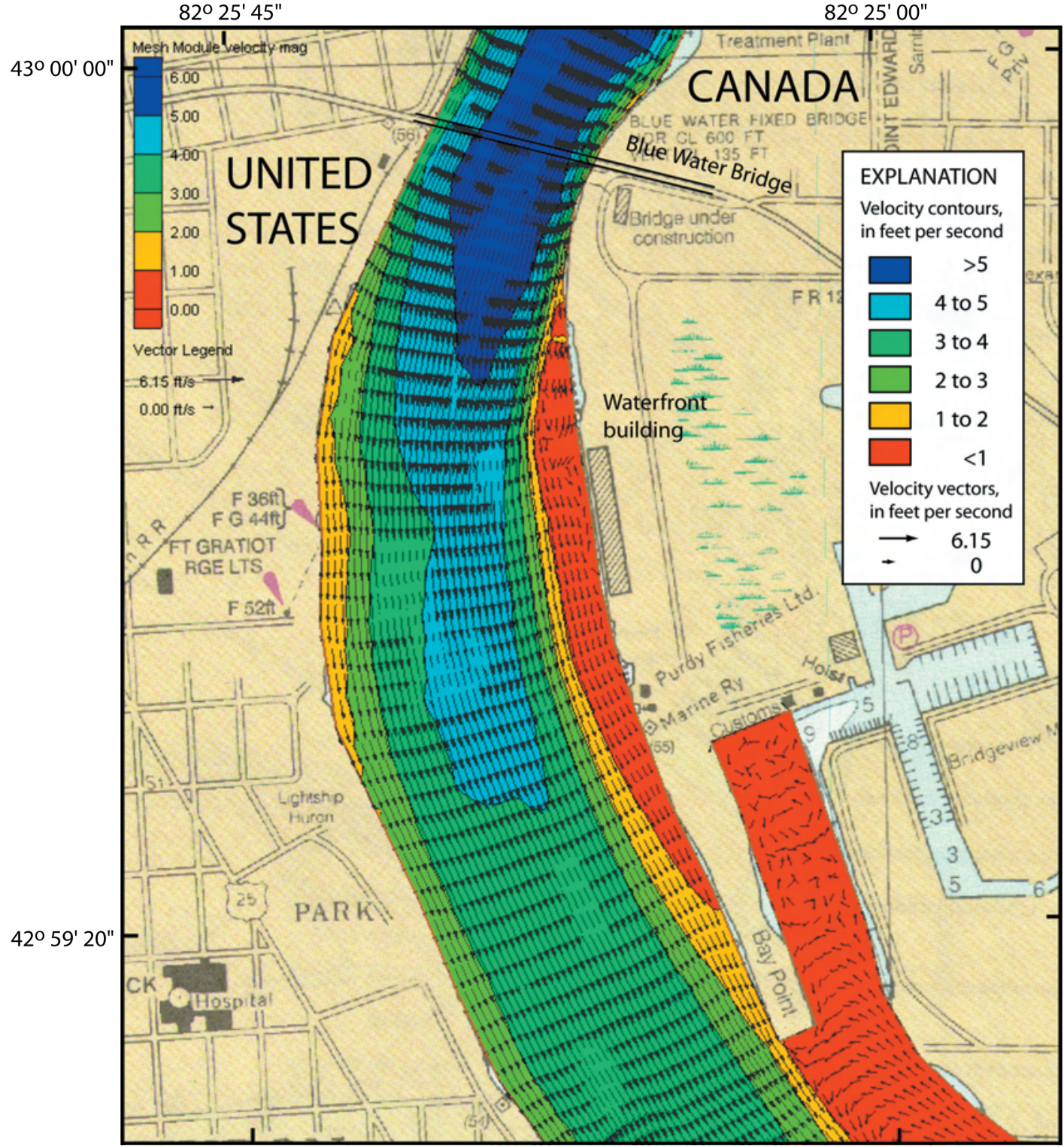

Base from National Oceanic and Atmospheric Administration 1:15,000 chart, 1999.

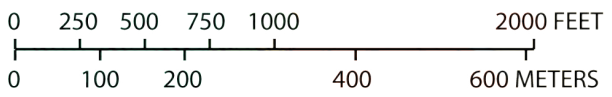

Figure 19. Simulated velocity field downstream from the Blue Water Bridge on Upper St. Clair River on refined mesh with Bendway Correction and Peclet number of 200. 


\section{Augementing Two-Dimensional Hydrodynamic Simulations with Measured Velocity Data to Identify Flow Paths as a Function of Depth on Upper St. Clair River in the Great Lakes Basin}

Mesh refinements, implementation of the Bendway Correction, and increasing the Peclet number from 21.9 to 200 improved the match between simulated and measured velocities. In particular, improvements in velocities were noted near the waterfront building, where earlier simulations had failed to suggest a large eddy structure that was measured during the July 2003 ADCP survey. A Peclet number of 200, however, is outside the reference range of 15 to 40 , so its utility in other areas of the waterway or for describing water-quality mixing characteristics is uncertain. It has apparent utility in Upper St. Clair River, perhaps because it allows the 2D model to better approximate 3D flow conditions.

\section{Integration of Velocity Information with Hydrodynamic Simulations}

Despite improvements in the match between simulated and measured velocities associated with enhancements to the hydrodynamic model of Upper St. Clair River, significant discrepancies remain between simulated and measured velocities downstream from the Blue Water Bridge. In addition, the 2D simulations do not provide information about possible differences in flow velocities with depth. To address these limitations, ADCP velocity data were integrated with simulation results for flow conditions during the July 2003 survey. The integrated results were converted into a binary solution-file format that was used to visualize the results.

Integrated velocities combine 2D simulated velocities and layer-dependent expected velocity innovations. Integrated velocities were computed for all ensembles, where present in a layer. In particular, the integrated easting and northing velocity components were computed as the sum of 2D simulated velocities, from quadratic interpolation, and the expected value of velocity innovations, based on bilinear interpolation, $\mathrm{f}_{\mathrm{BL}}$, from block-kriging estimates at ensemble locations:

$$
\begin{array}{ll}
\hat{U}_{E n s(x, y), l}=f_{Q} & \left(\tilde{U}_{\text {Node }(x, y, y,}, \operatorname{Ens}(x, y)\right)+f_{B L}(\mathrm{E}[\mathrm{v} \mid \bar{x}, \bar{y}, l], \operatorname{Ens}(x, y) \\
\hat{V}_{E n s(x, y), l=f_{Q}} & \left(\tilde{V}_{\text {Node }(x, y, y,}, \operatorname{Ens}(x, y)\right)+f_{B L}(\mathrm{E}[\mathrm{v} \mid \bar{x}, \bar{y}, l], \operatorname{Ens}(x, y)
\end{array}
$$

To assess the results, integrated velocities were averaged for all ADCP ensembles contained within each element, Elem(j), and represented as $\hat{\hat{U}}(j)_{E n s(x, y), l \in \operatorname{Elem}(j)}$ and $\overline{\hat{V}}(j)_{E n s(x, y), l \in E \operatorname{Elem}(j)}$ These results were compared with depth-averaged-within-layer, element-averaged values of measured easting and northing velocities represented as $\overline{\hat{v}}(j)_{\operatorname{Ens}(x, y), l \in \operatorname{Elem}(j)}$ and $\overline{\hat{u}}(j)_{\operatorname{Ens}(x, y), l \in \operatorname{Elem}(j)}$. Results generally show close agreement between integrated and measured velocities (fig. 20). 

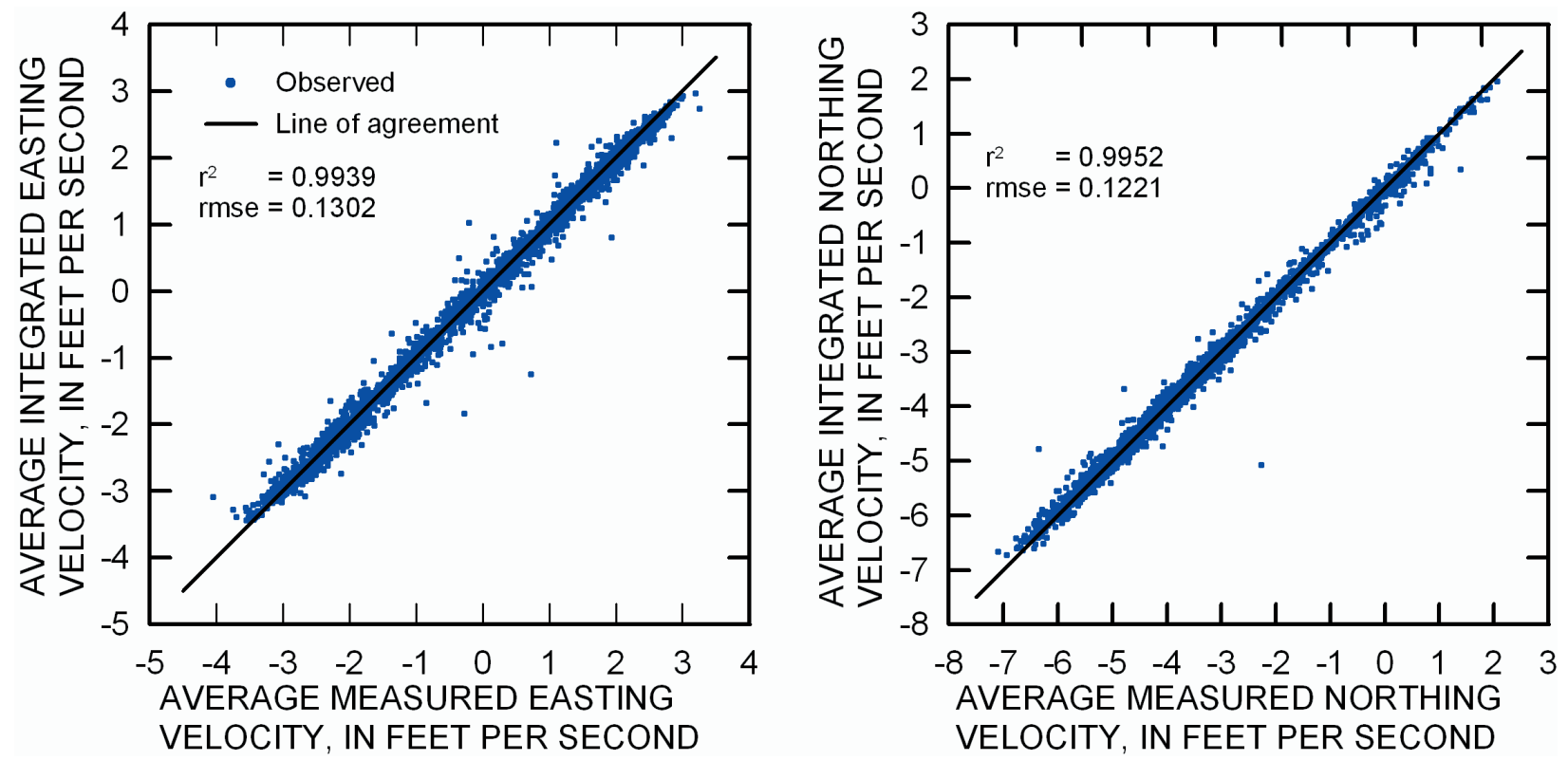

Figure 20. Relation between average measured and integrated velocities in layer 1 of Upper St. Clair River.

A statistical summary of element-averaged velocities measured in the 2003 ADCP survey and the integrated velocities is shown in table 3. Summary statistics include the bias, which indicates the average difference between measured and integrated values; the standard deviation, which indicates the standard deviation of differences between measured and integrated values; the root mean square error (RMSE), which is computed as the square root of the sum of the bias squared plus the standard deviation squared (variance); and the coefficient of determination $\left(r^{2}\right)$, which is the square of the linear correlation coefficient between measured and simulated values.

Resulting RMSEs for northing velocity components were consistently lower than those for easting velocity components, indicating a slightly more precise match for northing velocity components than for easting components. Furthermore, RMSEs generally increased and $r^{2}$ generally decreased with increasing layer number, indicating greater uncertainty in the match between measured and integrated velocities with depth below water surface. This greater uncertainty may be related to greater sensitivity of measured velocities to erratic boat movements, such as pitch, yaw, and roll, with increasing depth below the transducer. There is no indication of statistically significant discrepancies between element-averaged values of measured and integrated flows.

The integrated velocities at model nodes were computed as the sum of 2D simulated velocity components plus the expected values of velocity innovations estimated by use of bilinear interpolation from the kriging grid as

$$
\begin{aligned}
& \hat{U}_{E n s(x, y), l}=\tilde{U}_{\text {Node }(x, y)+} f_{B L}(\mathrm{E}[\mathrm{v} \mid \bar{x}, \bar{y}, l], \operatorname{Node}(x, y)) \\
& \hat{V}_{\text {Ens }(x, v) . l}=\tilde{V}_{\text {Node }(x, v)+} f_{R I}(\mathrm{~F}\lceil\mathrm{~V} \mid \bar{x} . \bar{v} . l 1 . \operatorname{Node}(x . v))
\end{aligned}
$$


Integrated velocities were computed for each layer and transformed into a binary solution file, by use of the format developed for RMA2 simulation results. Solution files with the layer-specific integrated velocities were used by the postprocessing software SMS (Environmental Modeling and Research Laboratory, 2003) to display layer-specific velocity patterns. Results indicate that the integrated velocities clearly map the recirculation zone downstream from the Blue Water Bridge near the shoreline building (fig. 21).

Table 3. Summary of relations between element-averaged measured and integrated velocities.

\begin{tabular}{|c|c|c|c|c|c|c|}
\hline Layer & $\begin{array}{c}\text { Number of } \\
\text { elements }\end{array}$ & $\begin{array}{l}\text { Velocity } \\
\text { component }\end{array}$ & $\begin{array}{c}\text { Bias } \\
\text { (feet per } \\
\text { second) }\end{array}$ & $\begin{array}{l}\text { Standard } \\
\text { deviation } \\
\text { (feet per } \\
\text { second) }\end{array}$ & $\begin{array}{l}\text { Root mean } \\
\text { square } \\
\text { error (feet } \\
\text { per second) }\end{array}$ & $\begin{array}{c}\text { Coefficient of } \\
\text { determination }\left(\mathrm{r}^{2}\right)\end{array}$ \\
\hline \multirow[t]{2}{*}{1} & 4,045 & Easting & -0.0002 & 0.1302 & 0.1302 & 0.9939 \\
\hline & & Northing & -.0002 & .1221 & .1221 & .9952 \\
\hline \multirow[t]{2}{*}{2} & 3,962 & Easting & .0006 & .1286 & .1286 & .9938 \\
\hline & & Northing & .0026 & .1229 & .1229 & .9949 \\
\hline \multirow[t]{2}{*}{3} & 3,802 & Easting & .0014 & .1405 & .1405 & .9925 \\
\hline & & Northing & .0030 & .1316 & .1316 & .9936 \\
\hline \multirow[t]{2}{*}{4} & 3,508 & Easting & .0014 & .1560 & .1560 & .9910 \\
\hline & & Northing & .0019 & .1386 & .1386 & .9911 \\
\hline \multirow[t]{2}{*}{5} & 2,864 & Easting & .0053 & .2158 & .2159 & .9842 \\
\hline & & Northing & .0063 & .1836 & .1837 & .9756 \\
\hline \multirow[t]{2}{*}{6} & 1,928 & Easting & .0010 & .2344 & .2344 & .9836 \\
\hline & & Northing & .0097 & .2279 & .2281 & .9519 \\
\hline \multirow[t]{2}{*}{7} & 922 & Easting & .0022 & .2719 & .2719 & .9783 \\
\hline & & Northing & .0026 & .2493 & .2493 & .9403 \\
\hline
\end{tabular}




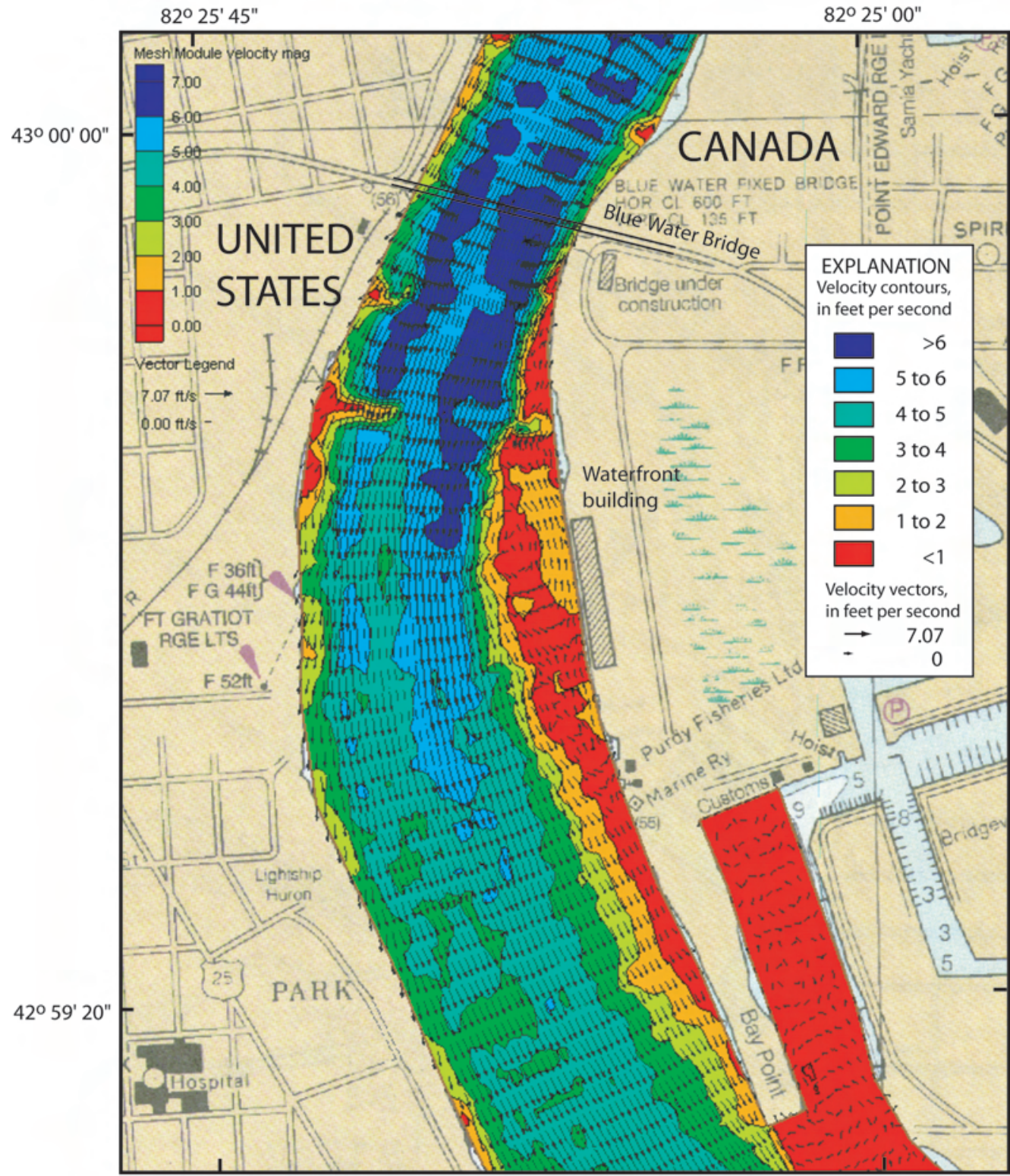

Base from National Oceanic and Atmospheric Administration 1:15,000 chart, 1999.

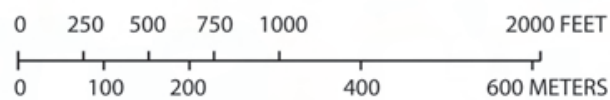

Figure 21. Integrated near-surface velocities in layer 1 of Upper St. Clair River downstream from the Blue Water Bridge. 


\section{Augementing Two-Dimensional Hydrodynamic Simulations with Measured Velocity Data to Identify Flow Paths as a Function of Depth on Upper St. Clair River in the Great Lakes Basin}

\section{Identification of Flow Path as a Function of Flow Depth}

Particle tracking provides a numerical procedure for following one or more hypothetical, massless particles through a velocity field. Forward particle tracking identifies the likely movement of one or more particles forward in time from an initial point of release to likely impact areas. Reverse particle tracking identifies areas that are likely a source or prior pass-through area for a terminal location. Reverse tracking changes the numerical sign of the velocities simulated at model nodes and provides a mechanism to track one or more particles backward in time. When many particles are specified at the starting location, independent random increments are commonly added to the advective movement specified by the velocity field to mimic dispersion or other submesh velocity components. When a single particle is specified at a starting location, particle tracking can be used without random increments to identify the expected flow path associated with the specified velocity field.

In this report, the particle-tracking code ParTrac developed by the U.S. Army Corps of Engineers (John Koschik, written commun., 2003) was used to investigate expected particle paths as a function of starting layer. Expected particle paths from reverse particle tracking based on integrated velocities in the top four layers of the Upper St. Clair River and a starting location near the city of Port Huron, Mich., sewage treatment plant are shown in figure 22. Reverse particle tracking results indicate that particle paths in shallower layers tend be nearer the Canadian boundary than particle paths in deeper waters. These results are consistent with near-surface velocities tracked by drifting-buoy deployments in Upper St. Clair River (Holtschlag and Aichele, 2001). Conversely, particles started in deeper waters, where public water intakes are commonly placed, are more likely to be consistent with particle tracks indicated by the public water intake version of the hydrodynamic model developed for the Michigan Source Water Assessment Program of the St. Clair-Detroit River Waterway (Holtschlag and Koschik, 2004). Particle paths for layers 5 through 7 are not continuous because of shallow-depth areas along the particle paths from the sewage treatment plant; therefore, those paths could not be shown. Particle paths do not account for possible vertical movement of particles between layers. A 3D hydrodynamic model would be needed to account for these effects and assess their importance on the identification of flow paths near public water intakes. 


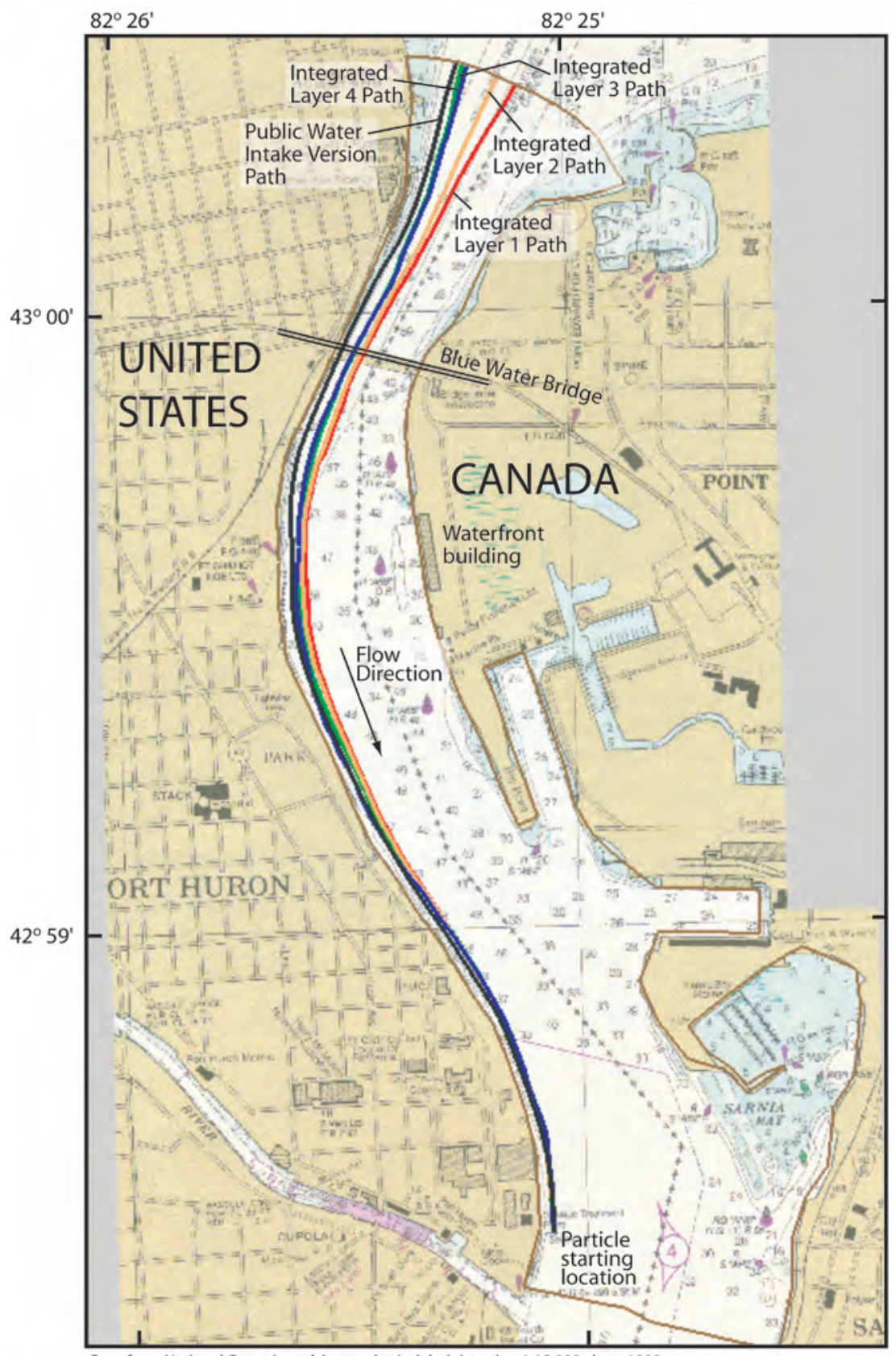

Base from National Oceanic and Atmospheric Administration 1:15,000 chart, 1999.

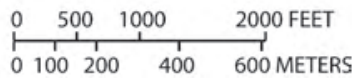

Figure 22. Flow paths as a function of depth (layer) in Upper St. Clair River from reverse particle-tracking for average flow conditions during July 1-3, 2003. 


\section{Augementing Two-Dimensional Hydrodynamic Simulations with Measured Velocity Data to Identify Flow Paths as a Function of Depth on Upper St. Clair River in the Great Lakes Basin}

\section{Summary and Conclusions}

In this report, Upper St. Clair River refers to a 2.5-mile reach of St. Clair River from Fort Gratiot, Mich., to a point near the mouth of the Black River in the Port Huron, Mich. area. St. Clair River, which forms part of the boundary between the U.S. and Canada, discharges an average of $182,000 \mathrm{ft}^{3} / \mathrm{s}$ from a drainage area of about 222,400 $\mathrm{mi}^{2}$. In this upper reach, St. Clair River has velocities that exceed $7 \mathrm{ft} / \mathrm{s}$, flow depths of up to $75 \mathrm{ft}$, and significant channel curvature that creates complex flow patterns downstream from the Blue Water Bridge.

Simulated velocities from a two-dimensional (depth-averaged) hydrodynamic model were augmented with horizontal flow information from an ADCP (acoustic Doppler current profiler) survey to characterize depth-dependent velocities in Upper St. Clair River. Discrepancies were previously detected between depth-averaged velocities simulated by a hydrodynamic model and surface velocities indicated by drifting-buoy deployments in Upper St. Clair River. A detailed ADCP survey was done along the upper $2.5 \mathrm{mi}$ of St. Clair River in the Port Huron, Mich. area during July 1-3, 2003, to resolve these discrepancies.

During the ADCP survey, about 2.1 million velocity measurements were obtained at 127 transects, which were separated by an average distance of about $100 \mathrm{ft}$. Along each transect, ensembles of velocity data were obtained at about 1-ft intervals. Each ensemble described the instantaneous easting, northing, and vertical water-velocity components in a set of vertically aligned cells ranging from $0.82 \mathrm{ft}(0.25 \mathrm{~m})$ to $3.28 \mathrm{ft}(1.00 \mathrm{~m})$ in depth throughout most of the water column. Velocities near the water surface and near the channel bottom, however, could not be measured directly because of instrument limitations.

To improve the resolution of simulated velocities, the finite-element mesh developed to identify flow paths near public water intakes on the St. Clair-Detroit River Waterway was refined within Upper St. Clair River by subdividing each of the 1,555 elements previously defined into four subelements. Velocities and water levels simulated by use of the public water intake version and the refined version of the mesh were confirmed to be similar. The Bendway Correction, a numerical technique that improves the accuracy of simulated flows in areas of channel curvature by accounting for vorticity, was implemented in the refined version of the model. This implementation improved the match between simulated and measured flows. Finally, the refined model with the Bendway Correction was recalibrated by increasing the Peclet number, which is used to assign eddy viscosity and control the local variability in simulated velocities, from 21.9 to 200 . Resulting simulations were better able to reproduce measured velocities.

Despite the generally improved match between simulated and measured velocities, enhanced model simulations of depthaveraged velocities were not fully consistent with surface velocities indicated by drifting-buoy deployments in Upper St. Clair River. In a further attempt to resolve the remaining discrepancies, the ADCP velocity data were used to adjust simulated velocities and identify possible variations in horizontal-velocity components with depth.

As a basis for adjustment, simulated velocities were computed for each ADCP ensemble by quadratic interpolation of velocities simulated with the enhanced model for flow boundary conditions during the July 1-3, 2003, survey. Differences between simulated and measured velocities were computed and are referred to as "velocity innovations." Average easting and northing components of velocity innovations were computed within seven layers of approximately $6.56 \mathrm{ft}(2 \mathrm{~m}) \mathrm{depth}$. The spatial correlation structure of the horizontal velocity innovations was analyzed within each layer by variogram analysis. Insufficient spatial correlation structure was detected in the vertical velocity components to permit estimation.

The results of the variogram analysis were used with block kriging to map the spatial variation in expected innovations onto a grid of 20-ft-square cells that spanned the model area. Bilinear interpolation from this grid was used to compute the expected innovation at model nodes. Integrated velocities, which were computed as the sum of simulated velocities and expected innovations within each layer, were used to map the spatial variation in flow velocities with depth. Integrated flow velocities reproduced a large secondary circulation pattern about 1,800 ft downstream from the Blue Water Bridge that was measured during the ADCP survey. Expected particle paths generated with the integrated velocities showed that surface velocities in the upper layers tended to originate nearer the Canadian shoreline than velocities near the channel bottom in the lower layers. Therefore, flow paths near U.S. public water intakes on the river bottom are more likely to be in the United States than those for withdrawals near the water surface, assuming any vertical movement of particles can be ignored. Finally, integrated velocities in the upper layers are generally consistent with the surface velocities indicated by drifting-buoy deployments.

Neither the 2D hydrodynamic model nor the velocity measurements provided sufficient information to describe the vertical component of flow in this report. This limitation resulted in the inability to account for vertical movements on expected flow paths through Upper St. Clair River. A 3D hydrodynamic model would be needed to account for these effects and assess their importance on the identification of flow paths near public water intakes. 


\section{Acknowledgments}

Christopher Rayburn, Research Management Director, American Water Works Association Research Foundation; Ramesh Kashinkunti, Senior Engineer, Department of Water Works, City of Cincinnati, Ohio; and Scott Wells, Professor and Chair of Environmental Engineering, Portland State University, provided technical direction and review. Don James, USGS Grayling Mich., Office, and Paul Taylor and Benjamin Harrison, USACE Detroit District, operated the ADCP units during the velocity survey.

\section{References Cited}

de Marsily, Ghislain, 1986, Quantitative hydrogeology—Groundwater hydrology for engineers: Orlando, Fl., Academic Press, $440 \mathrm{p}$.

Donnell, B.P., Letter, J.V., Jr., McAnally, W.H., and Thomas, W.A., 2003, Users guide to RMA2-WES (version 4.5): U.S. Army Corps of Engineers Waterways Experiment Station, Vicksburg, Miss., 264 p., accessed March 17, 2005 at http://chl.wes.army. mil/software/tabs/docs.htp.

Environmental Modeling Research Laboratory, 2003, SMS Surface-Water Modeling System reference manual (version 7): Provo, Utah, Environmental Modeling Systems, Inc., 342 p.

Holtschlag, D.J., and Aichele, S.A., 2001, Visualization of drifting buoy deployments on St. Clair River near public water intakes-October 3-5, 2000: U.S. Geological Survey Open-File Report 01-17, accessed March 17, 2005, at http:/h mi.water.usgs.gov/splan2/sp08903/SCRIndex.html

Holtschlag, D. J., and Koschik, J.A., 2002, A two-dimensional hydrodynamic model of the St. Clair-Detroit River Waterway in the Great Lakes Basin: U.S. Geological Survey Water-Resources Investigations Report 01-4236, 63 p. accessed March 17, 2005, at http://mi.water.usgs.gov/pubs/WRIR/WRIR01-4236/

Holtschlag, D.J., and Koschik, J.A., 2003a, An acoustic Doppler current profiler survey of flow velocities in St. Clair River, a connecting channel of the Great Lakes: U.S. Geological Survey Open-File Report 03-119, accessed March 17, 2005, at http://mi.water.usgs.gov/pubs/OF/OF03-119/

Holtschlag, D.J., and Koschik, J.A., 2003b, An acoustic Doppler current profiler survey of flow velocities in Detroit River, a connecting channel of the Great Lakes, U.S. Geological Survey Open-File Report 03-219, accessed March 17, 2005, at http://mi.water.usgs.gov/pubs/OF/OF03-219/

Holtschlag, D.J., and Koschik, J.A., 2004, Hydrodynamic simulation and particle-tracking techniques for identification of source areas to public-water intakes on the St. Clair-Detroit River Waterway in the Great Lakes Basin: U.S. Geological Survey Scientific Investigations Report 2004-5072, 29 p., accessed March 17, 2005, at http://water.usgs.gov/pubs/sir/2004/5072

National Oceanic and Atmospheric Administration, 1999, Recreational chart 14583: Detroit River, Lake St. Clair, and St. Clair River: U.S. Department of Commerce, National Ocean Service, Washington, D.C.

Schwab, D.J., Clites, A.H., Murthy, C.R., Sandall, J.E., Meadows, L.A., and Meadows, G.A., 1989, The effect of wind on transport and circulation in Lake St. Clair: Journal of Geophysical Research, v. 94, no. C4, p. 4947-4958.

Simpson, M.R., 2001, Discharge measurements using a broad-band acoustic Doppler current profiler: U.S. Geological Survey Open-File Report 01-1, 123 p., accessed March 17, 2005, at http://water.usgs.gov/pubs/of/ofr0101/text.pdf

Tsanis, I.K., Shen, Huihua, and Venkatesh, S., 1996, Water currents in the St. Clair and Detroit Rivers: Journal of Great Lakes Research, v. 22, no. 2, p. 213-223.

Williamson, D.C., Scott R.D., and Lord, Stephen, 1997, Numerical modeling of the St. Clair/Detroit River system and seasonal variations in head loss, in Proceedings of the 1997 Canadian Coastal Conference, Guelph, Ontario, May 21-24, 1997: Canadian Coastal Science and Engineering Association, p. 176-184. 
Appendix 1. Summary of acoustic Doppler current profiler velocity data for transects on the Upper St. Clair River. [USGS-U.S. Geological Survey, USACE-U.S. Army Corps of Engineers. Transect locations shown in figs. 3-6]

\begin{tabular}{|c|c|c|c|c|c|c|c|}
\hline Transect number & $\begin{array}{l}\text { Date and Eastern } \\
\text { standard time of } \\
\text { transect start }\end{array}$ & $\begin{array}{l}\text { Total } \\
\text { discharge } \\
\text { [cubic feet } \\
\text { per second] }\end{array}$ & $\begin{array}{l}\text { Number of } \\
\text { ensembles }\end{array}$ & $\begin{array}{l}\text { Max } \\
\text { depth } \\
\text { [feet] }\end{array}$ & $\begin{array}{l}\text { Bin size } \\
\text { [centi- } \\
\text { meters] }\end{array}$ & $\begin{array}{l}\text { Left }(\mathrm{L}) \text { or } \\
\text { right }(\mathrm{R}) \text { bank } \\
\text { start }\end{array}$ & Agency \\
\hline 0020 & 7/3/03 8:14 & 166,682 & 1,087 & 74.7 & 50 & $\mathrm{~L}$ & USGS \\
\hline 0030 & 7/3/03 8:33 & 169,091 & 1,210 & 74.7 & 50 & $\mathrm{R}$ & USGS \\
\hline 0040 & 7/3/03 8:45 & 171,494 & 780 & 68.6 & 50 & $\mathrm{~L}$ & USGS \\
\hline 0070 & $7 / 2 / 03$ 16:07 & 172,814 & 1,357 & 69.5 & 50 & $\mathrm{R}$ & USGS \\
\hline 0080 & 7/3/03 9:10 & 175,200 & 709 & 68.6 & 50 & $\mathrm{~L}$ & USGS \\
\hline 0090 & $7 / 2 / 03 \quad 15: 58$ & 174,832 & 863 & 68.8 & 50 & $\mathrm{~L}$ & USGS \\
\hline 0100 & 7/3/03 9:18 & 175,980 & 678 & 68.1 & 50 & $\mathrm{R}$ & USGS \\
\hline 0110 & $7 / 2 / 03$ 15:50 & 177,449 & 807 & 64.8 & 50 & $\mathrm{R}$ & USGS \\
\hline 0160 & 7/3/03 10:03 & 179,906 & 920 & 60.0 & 50 & $\mathrm{R}$ & USGS \\
\hline 0170 & $7 / 2 / 03 \quad 15: 28$ & 177,257 & 682 & 60.0 & 50 & $\mathrm{~L}$ & USGS \\
\hline 0180 & $7 / 2 / 0314: 11$ & 185,446 & 688 & 59.3 & 25 & $\mathrm{~L}$ & USACE \\
\hline 0181 & $7 / 3 / 03$ 10:14 & 177,160 & 605 & 60.1 & 50 & $\mathrm{~L}$ & USGS \\
\hline 0190 & $7 / 2 / 03$ 15:21 & 172,104 & 686 & 70.2 & 50 & $\mathrm{R}$ & USGS \\
\hline 0200 & $7 / 3 / 03$ 10:21 & 176,428 & 601 & 78.0 & 50 & $\mathrm{R}$ & USGS \\
\hline 0201 & $7 / 2 / 03$ 13:57 & 182,387 & 509 & 77.8 & 25 & $\mathrm{~L}$ & USACE \\
\hline 0202 & $7 / 2 / 03$ 14:03 & 180,137 & 641 & 78.3 & 25 & $\mathrm{R}$ & USACE \\
\hline 0220 & $7 / 2 / 03$ 13:51 & 189,383 & 442 & 66.0 & 25 & $\mathrm{R}$ & USACE \\
\hline 0230 & $7 / 2 / 03 \quad 14: 59$ & 166,149 & 879 & 60.5 & 50 & $\mathrm{~L}$ & USGS \\
\hline 0240 & $7 / 2 / 03$ 13:43 & 189,210 & 536 & 60.5 & 25 & $\mathrm{~L}$ & USACE \\
\hline 0310 & $7 / 2 / 03$ 14:17 & 176,967 & 686 & 47.5 & 50 & $\mathrm{~L}$ & USGS \\
\hline 0320 & $7 / 2 / 03$ 13:09 & 170,526 & 544 & 46.8 & 25 & $\mathrm{~L}$ & USACE \\
\hline 0321 & $7 / 2 / 03 \quad 13: 14$ & 173,373 & 387 & 46.8 & 25 & $\mathrm{R}$ & USACE \\
\hline 0330 & 7/2/03 14:08 & 178,186 & 645 & 46.2 & 50 & $\mathrm{R}$ & USGS \\
\hline 0340 & $7 / 2 / 03 \quad 12: 42$ & 175,458 & 591 & 46.3 & 25 & $\mathrm{R}$ & USACE \\
\hline 0350 & $7 / 2 / 03$ 13:59 & 175,607 & 1,062 & 47.9 & 50 & $\mathrm{~L}$ & USGS \\
\hline 0360 & $7 / 2 / 03 \quad 12: 30$ & 178,532 & 1,160 & 47.4 & 25 & $\mathrm{~L}$ & USACE \\
\hline 0370 & $7 / 2 / 03 \quad 13: 39$ & 188,972 & 737 & 49.4 & 50 & $\mathrm{R}$ & USGS \\
\hline 0380 & $7 / 2 / 03 \quad 12: 21$ & 175,911 & 562 & 56.1 & 25 & $\mathrm{R}$ & USACE \\
\hline 0390 & $7 / 2 / 03$ 13:31 & 180,994 & 825 & 61.5 & 50 & $\mathrm{~L}$ & USGS \\
\hline 0395 & $7 / 2 / 03$ 13:23 & 178,645 & 726 & 69.5 & 50 & $\mathrm{R}$ & USGS \\
\hline 0400 & $7 / 2 / 03 \quad 12: 13$ & 172,165 & 686 & 69.5 & 25 & $\mathrm{~L}$ & USACE \\
\hline 0410 & 7/2/03 13:04 & 170,068 & 882 & 70.4 & 50 & $\mathrm{R}$ & USGS \\
\hline 0411 & $7 / 2 / 0313: 14$ & 161,713 & 781 & 70.2 & 50 & $\mathrm{~L}$ & USGS \\
\hline 0420 & $7 / 2 / 03$ 12:04 & 169,862 & 750 & 66.5 & 25 & $\mathrm{R}$ & USACE \\
\hline 0430 & $7 / 2 / 03 \quad 12: 55$ & 169,203 & 977 & 64.9 & 50 & $\mathrm{~L}$ & USGS \\
\hline 0440 & $7 / 2 / 0311: 38$ & 181,706 & 546 & 62.1 & 25 & $\mathrm{R}$ & USACE \\
\hline
\end{tabular}


Appendix 1. Summary of acoustic Doppler current profiler velocity data for transects on the Upper St. Clair River.--Continued

\begin{tabular}{|c|c|c|c|c|c|c|c|}
\hline Transect number & $\begin{array}{l}\text { Date and Eastern } \\
\text { standard time of } \\
\text { transect start }\end{array}$ & $\begin{array}{l}\text { Total } \\
\text { discharge } \\
\text { [cubic feet } \\
\text { per second] }\end{array}$ & $\begin{array}{l}\text { Number of } \\
\text { ensembles }\end{array}$ & $\begin{array}{l}\text { Max } \\
\text { depth } \\
\text { [feet] }\end{array}$ & $\begin{array}{l}\text { Bin size } \\
\text { [centi- } \\
\text { meters] }\end{array}$ & $\begin{array}{l}\text { Left }(\mathrm{L}) \text { or } \\
\text { right }(\mathrm{R}) \text { bank } \\
\text { start }\end{array}$ & Agency \\
\hline 0455 & $7 / 2 / 03$ 12:47 & 163,449 & 826 & 63.7 & 50 & $\mathrm{R}$ & USGS \\
\hline 0460 & $7 / 2 / 0311: 50$ & 178,591 & 777 & 61.8 & 25 & $\mathrm{~L}$ & USACE \\
\hline 0470 & $7 / 2 / 0312: 27$ & 166,247 & 775 & 65.8 & 50 & $\mathrm{R}$ & USGS \\
\hline 0485 & $7 / 2 / 0312: 15$ & 174,812 & 1,108 & 65.6 & 50 & $\mathrm{~L}$ & USGS \\
\hline 0490 & $7 / 2 / 03$ 12:05 & 183,429 & 929 & 52.1 & 50 & $\mathrm{R}$ & USGS \\
\hline 0500 & 7/2/03 11:06 & 161,462 & 694 & 51.8 & 25 & $\mathrm{~L}$ & USACE \\
\hline 0510 & $7 / 2 / 03$ 11:55 & 169,916 & 1,050 & 51.3 & 50 & $\mathrm{~L}$ & USGS \\
\hline 0520 & $7 / 2 / 0310: 57$ & 152,865 & 602 & 48.8 & 25 & $\mathrm{R}$ & USACE \\
\hline 0570 & $7 / 2 / 0311: 28$ & 175,023 & 887 & 49.7 & 50 & $\mathrm{R}$ & USGS \\
\hline 0580 & 7/2/03 9:47 & 172,610 & 1,637 & 49.0 & 100 & $\mathrm{~L}$ & USACE \\
\hline 0590 & $7 / 2 / 0311: 15$ & 182,370 & 1,102 & 50.2 & 50 & $\mathrm{~L}$ & USGS \\
\hline 0600 & 7/2/03 9:38 & 176,172 & 1,044 & 50.6 & 100 & $\mathrm{R}$ & USACE \\
\hline 0610 & $7 / 2 / 03$ 11:05 & 180,691 & 977 & 52.2 & 50 & $\mathrm{R}$ & USGS \\
\hline 0620 & 7/2/03 9:28 & 173,538 & 1,586 & 50.9 & 100 & $\mathrm{~L}$ & USACE \\
\hline 0630 & $7 / 2 / 0310: 55$ & 173,949 & 987 & 52.9 & 50 & $\mathrm{~L}$ & USGS \\
\hline 0640 & 7/2/03 8:59 & 173,470 & 1,777 & 51.5 & 100 & $\mathrm{R}$ & USACE \\
\hline 0650 & $7 / 2 / 03$ 10:48 & 171,808 & 758 & 51.8 & 50 & $\mathrm{R}$ & USGS \\
\hline 0660 & 7/2/03 8:46 & 177,409 & 1,756 & 51.1 & 100 & $\mathrm{~L}$ & USACE \\
\hline 0670 & $7 / 2 / 03$ 10:36 & 166,585 & 1,315 & 52.0 & 50 & $\mathrm{~L}$ & USGS \\
\hline 0760 & 7/1/03 16:50 & 177,807 & 1,668 & 48.3 & 100 & $\mathrm{R}$ & USACE \\
\hline 0770 & 7/2/03 9:42 & 174,004 & 1,130 & 48.1 & 50 & $\mathrm{R}$ & USGS \\
\hline 0780 & 7/1/03 16:37 & 176,362 & 1,972 & 48.2 & 100 & $\mathrm{~L}$ & USACE \\
\hline 0790 & 7/2/03 9:32 & 173,716 & 1,083 & 51.3 & 50 & $\mathrm{~L}$ & USGS \\
\hline 0800 & 7/1/03 16:27 & 177,992 & 1,168 & 52.0 & 100 & $\mathrm{R}$ & USACE \\
\hline 0810 & 7/2/03 9:21 & 177,707 & 1,280 & 49.5 & 50 & $\mathrm{R}$ & USGS \\
\hline 0820 & 7/1/03 16:17 & 174,593 & 1,681 & 48.8 & 100 & $\mathrm{~L}$ & USACE \\
\hline 0830 & $7 / 2 / 038: 56$ & 174,808 & 1,723 & 49.4 & 50 & $\mathrm{~L}$ & USGS \\
\hline 0840 & 7/1/03 16:04 & 176,021 & 1,782 & 49.2 & 100 & $\mathrm{R}$ & USACE \\
\hline 0850 & 7/2/03 8:44 & 180,621 & 1,313 & 48.7 & 50 & $\mathrm{R}$ & USGS \\
\hline 0860 & 7/1/03 15:48 & 180,317 & 2,607 & 48.8 & 100 & $\mathrm{~L}$ & USACE \\
\hline 0870 & 7/1/03 17:32 & 171,461 & 1,410 & 49.1 & 50 & $\mathrm{~L}$ & USGS \\
\hline 0880 & $7 / 1 / 03$ 15:21 & 174,214 & 1,510 & 48.9 & 100 & $\mathrm{R}$ & USACE \\
\hline 0885 & $7 / 1 / 03$ 17:20 & 182,763 & 1,381 & 48.3 & 50 & $\mathrm{R}$ & USGS \\
\hline 0890 & 7/1/03 17:05 & 169,704 & 1,838 & 46.5 & 50 & $\mathrm{~L}$ & USGS \\
\hline 0900 & 7/1/03 15:06 & 170,348 & 2,422 & 45.4 & 100 & $\mathrm{~L}$ & USACE \\
\hline 0910 & 7/1/03 16:56 & 176,914 & 861 & 45.1 & 50 & $\mathrm{R}$ & USGS \\
\hline
\end{tabular}


Appendix 1. Summary of acoustic Doppler current profiler velocity data for transects on the Upper St. Clair River.--Continued

\begin{tabular}{|c|c|c|c|c|c|c|c|}
\hline Transect number & $\begin{array}{l}\text { Date and Eastern } \\
\text { standard time of } \\
\text { transect start }\end{array}$ & $\begin{array}{l}\text { Total } \\
\text { discharge } \\
\text { [cubic feet } \\
\text { per second] }\end{array}$ & $\begin{array}{l}\text { Number of } \\
\text { ensembles }\end{array}$ & $\begin{array}{l}\text { Max } \\
\text { depth } \\
\text { [feet] }\end{array}$ & $\begin{array}{l}\text { Bin size } \\
\text { [centi- } \\
\text { meters] }\end{array}$ & $\begin{array}{l}\text { Left }(\mathrm{L}) \text { or } \\
\text { right }(\mathrm{R}) \text { bank } \\
\text { start }\end{array}$ & Agency \\
\hline 0930 & $7 / 1 / 03$ 16:44 & 173,613 & 1,292 & 42.8 & 50 & $\mathrm{~L}$ & USGS \\
\hline 0940 & $7 / 1 / 03 \quad 14: 26$ & 188,528 & 2,777 & 43.9 & 100 & $\mathrm{~L}$ & USACE \\
\hline 0950 & $7 / 1 / 0316: 35$ & 176,936 & 828 & 42.4 & 50 & $\mathrm{R}$ & USGS \\
\hline 0980 & 7/1/03 13:48 & 174,333 & 1,300 & 44.5 & 100 & $\mathrm{~L}$ & USACE \\
\hline 0990 & 7/1/03 16:11 & 173,994 & 1,121 & 45.0 & 50 & $\mathrm{R}$ & USGS \\
\hline 1000 & $7 / 1 / 0313: 35$ & 173,130 & 1,426 & 45.2 & 100 & $\mathrm{R}$ & USACE \\
\hline 1005 & $7 / 1 / 03$ 15:55 & 174,942 & 1,763 & 45.4 & 50 & $\mathrm{~L}$ & USGS \\
\hline 1010 & 7/1/03 15:39 & 173,573 & 1,716 & 44.2 & 50 & $\mathrm{R}$ & USGS \\
\hline 1035 & $7 / 1 / 03 \quad 14: 22$ & 180,672 & 1,729 & 41.9 & 50 & $\mathrm{R}$ & USGS \\
\hline 1040 & 7/1/03 13:02 & 179,862 & 2,364 & 41.5 & 100 & $\mathrm{R}$ & USACE \\
\hline 1045 & $7 / 1 / 0312: 56$ & 168,887 & 2,016 & 42.0 & 50 & $\mathrm{~L}$ & USGS \\
\hline 1050 & 7/1/03 12:11 & 174,105 & 2,146 & 42.2 & 50 & $\mathrm{~L}$ & USGS \\
\hline 1060 & 7/1/03 12:45 & 177,917 & 2,899 & 41.2 & 100 & $\mathrm{~L}$ & USACE \\
\hline 1070 & 7/1/03 11:58 & 175,014 & 1,428 & 39.6 & 50 & $\mathrm{R}$ & USGS \\
\hline 1080 & $7 / 1 / 03$ 12:31 & 174,824 & 2,001 & 38.1 & 100 & $\mathrm{R}$ & USACE \\
\hline 1090 & 7/1/03 11:42 & 178,930 & 1,871 & 38.8 & 50 & $\mathrm{~L}$ & USGS \\
\hline 1101 & 7/1/03 12:11 & 176,815 & 3,445 & 40.1 & 100 & $\mathrm{~L}$ & USACE \\
\hline 1111 & $7 / 1 / 0311: 32$ & 173,174 & 1,005 & 42.2 & 50 & $\mathrm{R}$ & USGS \\
\hline
\end{tabular}


